\title{
Cadmium Stress Reprograms ROS/RNS Homeostasis in Phytophthora infestans (Mont.) de Bary
}

\author{
Joanna Gajewska ${ }^{1}$, Nur Afifah Azzahra ${ }^{1}$, Özgün Ali Bingö1 ${ }^{2}{ }^{\circledR}$, Karolina Izbiańska-Jankowska ${ }^{1}$, \\ Tomasz Jelonek $^{3}{ }^{\circledR}$, Joanna Deckert ${ }^{1}$, Jolanta Floryszak-Wieczorek ${ }^{4}$ and \\ Magdalena Arasimowicz-Jelonek ${ }^{1, *}$ \\ 1 Department of Plant Ecophysiology, Institute of Experimental Biology, Faculty of Biology, Adam Mickiewicz \\ University Poznań, Uniwersytetu Poznańskiego 6, 61-614 Poznań, Poland; \\ joanna.gajewska@amu.edu.pl (J.G.); nurafifahaz92@gmail.com (N.A.A.); \\ karolina.izbianska@amu.edu.pl (K.I.-J.); Joanna.Deckert@amu.edu.pl (J.D.) \\ 2 Department of Biology, Eskisehir Technical University, 26555 Eskisehir, Turkey; ozgunalibingol@gmail.com \\ 3 Department of Forest Utilization, Poznań University of Life Sciences, Wojska Polskiego 71A, 60-625 Poznań, \\ Poland; tomasz.jelonek@up.poznan.pl \\ 4 Department of Plant Physiology, Poznan University of Life Sciences, Wołynska 35, 60-637 Poznań, Poland; \\ jolanta.floryszak@up.poznan.pl \\ * Correspondence: arasim@amu.edu.pl; Tel.: + 48-61-829-5808
}

Received: 14 October 2020; Accepted: 5 November 2020; Published: 8 November 2020

\begin{abstract}
Heavy metal pollution causes many soils to become a toxic environment not only for plants, but also microorganisms; however, little is known how heavy metal contaminated environment affects metabolism of phytopathogens and their capability of infecting host plants. In this study the oomycete Phytophthora infestans (Mont.) de Bary, the most harmful pathogen of potato, growing under moderate cadmium stress $(\mathrm{Cd}, 5 \mathrm{mg} / \mathrm{L})$ showed nitro-oxidative imbalance associated with an enhanced antioxidant response. Cadmium notably elevated the level of nitric oxide, superoxide and peroxynitrite that stimulated nitrative modifications within the RNA and DNA pools in the phytopathogen structures. In contrast, the protein pool undergoing nitration was diminished confirming that protein tyrosine nitration is a flexible element of the oomycete adaptive strategy to heavy metal stress. Finally, to verify whether $\mathrm{Cd}$ is able to modify $P$. infestans pathogenicity, a disease index and molecular assessment of disease progress were analysed indicating that $\mathrm{Cd}$ stress enhanced aggressiveness of $\mathrm{vr} P$. infestans towards various potato cultivars. Taken together, $\mathrm{Cd}$ not only affected hyphal growth rate and caused biochemical changes in P. infestans structures, but accelerated the pathogenicity as well. The nitro-oxidative homeostasis imbalance underlies the phytopathogen adaptive strategy and survival in the heavy metal contaminated environment.
\end{abstract}

Keywords: reactive oxygen and nitrogen species; fungal-like organism; pathogenicity; late blight disease; heavy metal pollution

\section{Introduction}

Environment contamination by heavy metals is a huge problem in many parts of the world. The rate of the global deposition of heavy metals in soil has dramatically increased over the past two centuries [1]. Therefore, it is currently a serious threat not only to plants and microorganisms, but also to all biotic interactions, in which at least one of the components is exposed to the metals [2,3]. Heavy metals may be divided into the elements, which in small amounts are essential for living organisms (e.g., chromium, iron, zinc) and the elements of an unknown physiological role (e.g., cadmium, lead, mercury), which are considered toxic for many organisms including animals, plants, and microorganisms [4]. The former 
group of heavy metals is called essential and the latter nonessential elements. Nonetheless, both of these groups can be toxic for living organisms in higher than the critical concentrations [5]. One of the nonessential metals that is relatively widely distributed in nature (air, sediment, soil, water) and released into the environment in the amount of about 30,000 tonnes per year is cadmium (Cd) [6]. As a highly mobile, redox-inactive metal, $\mathrm{Cd}$ is easily absorbed by living organisms, which can exert its negative effects related to morphological, structural, and molecular changes. Importantly, Cd-dependent gene expression could be regulated by changes in the activity of transcription factors, the modulation of micro RNA levels, and modifications in chromatin [7].

In general, metals considered as nonessential elements disrupt the proper functioning of the organism, resulting in a stress status. One of the earliest reactions to these heavy metals noted in various model organisms is reactive oxygen and nitrogen species (ROS/RNS) generation [8]. An uncontrolled accumulation of both ROS and RNS can provoke alteration of the cell redox balance resulting in oxidative/nitrative modifications of biomolecules that contribute to the heavy metal toxicity [8]. On the other hand, ROS/RNS are ubiquitous signaling molecules engaged not only in growth and development, but also in stress recognition, signal transduction, and the response to stress factors facilitating alleviation of heavy metal toxicity [9-11]. The final effect of ROS/RNS on the cellular environment is dependent on their turnover, which includes production and detoxification pathways $[12,13]$.

While the mechanisms associated with the microorganism response to essential metals such as copper, iron, and zinc have been extensively studied and reviewed [14-17], the response to nonessential metals is definitely less recognized, especially with regard to fungal and fungal-like pathogens. In general, heavy metals primarily affect fungal growth and morphology [18]. These effects as a consequence to heavy metal exposure were observed e.g., in Phanerochaete chrysosporium Burds. [18], Fusarium oxysporum Schlecht. [19], Botrytis cinerea Pers., Alternaria alternata (Fr.) Keissl. [20], Aspergillus niger van Tieghem, and Penicillium citrinum Thom [21]. Moreover, in the white-rot fungus P. chrysosporium [13] and in filamentous yeast Trichosporon cutaneum Kreger-van Rij [22] heavy metals induced oxidative stress and antioxidant enzyme activity. A similar heavy metal-dependent effects were observed in fungal-like oomycetes. Briefly, the metal reduced hyphae area and radial extension in Pythium debaryanum Hesse, Achlya bisexualis Coker and Couch, Saprolegnia delica Coker, Dictyuchus carpophorus Zopf., and Phytophthora capsici Leo. [23-25]. Moreover, in P. capsici heavy metal-limited hyphal growth was accompanied by reduced sporulation and even virulence manifested by the decreased expression of the laccase PcLAC2 and necrosis-inducing NLP protein PcNLP14 genes [25]. Thus, recognition of heavy metal impact on the biology and pathobiology of economically important phytopathogens seems to have a priority in the constantly progressing pollution of the environment.

One of the most dangerous oomycete plant pathogens on the global scale, generating huge losses in potato yield is Phytophthora infestans (Mont) de Bary [26]. As a causative agent of late blight it was responsible for the great Irish famine in the 19th century and even today this disease causes enormous yield losses estimated at USD 3 billion per year worldwide [26,27]. Importantly, P. infestans is capable of a very rapid evolution and adaptation to unfavorable environment conditions, causing inefficiency in the pathogen control [28]. Under natural conditions the pathogen survives winter in the soil as sexual oospores or as hyphae in infected plant debris, thus heavy metals deposited in the soil may affect $P$. infestans metabolism and its pathogenicity. It worth pointing that the natural $\mathrm{Cd}$ concentration in soil is relatively low, and soil contamination with $\mathrm{Cd}$ is mainly the result of human activities such as smelting, mining, electroplating [29], fossil fuel combustion, metallurgical works, sewage sludge, municipal and industrial wastes [30]. Unfortunately, there is no experimental knowledge concerning the oomycete response to the abiotic stress. The latest reports on P. infestans metabolism revealed RNS formation in the pathogen structures as an integral part of the pathogen biology and adaptation strategy to the host environment [31]. It should be noted that in filamentous fungi as microorganisms similar in morphology and habitat to the oomycetes, nitric oxide (NO) has also been implicated in abiotic stress responses. For example, mitochondrial NO production was observed in yeast cells exposed to 
anoxia [32]. In turn, enrichment of yeast cells with $\mathrm{NO}$ provided protection against oxidative stress provoked by heavy metals, heat shock stress, and high hydrostatic pressure [33,34]. In view of the above, the main aim of this study was to determine the effect of $\mathrm{Cd}$, as a model heavy metal stress, on the nitro-oxidative status in P. infestans structures as well as the oomycete pathogenicity.

\section{Results}

\subsection{Cadmium Stress Affects P. infestans in Vitro Growth and Sporulation}

To assess a direct effect of $\mathrm{Cd}$ stress on $P$. infestans in vitro growth and sporulation, different concentrations of $\mathrm{Cd}$ supplied to the medium as $\mathrm{CdCl}_{2}$ were used $(0-25 \mathrm{mg} / \mathrm{L})$, allowing to determine the tolerance index of $P$. infestans to the heavy metal. The results showed that $\mathrm{Cd}$ significantly limited in vitro growth of the oomycete and the concentrations up to $5 \mathrm{mg} / \mathrm{L}$ of $\mathrm{Cd}$ included in the tolerance limit noted for P. infestans (Figure S1). Thus, $5 \mathrm{mg} / \mathrm{L}$ of Cd caused ca. $50 \%$ decrease of hyphal growth and reflected moderate heavy metal stress, whereas $12.5 \mathrm{mg} / \mathrm{L}$ of $\mathrm{Cd}$ caused ca. $75 \%$ decrease of hyphal growth area and was described as sublethal $\mathrm{Cd}$ stress (Figure 1A). Both $\mathrm{Cd}$ concentrations inhibited also sporangia formation and spore germination (Figure 1B,C). The amount of sporangia was reduced by $48 \%$ and $68 \%$ in response to 5 and $12.5 \mathrm{mg} / \mathrm{L}$ of Cd, respectively (Figure 1B). Additionally, both Cd doses delayed germination of spores to a similar degree: ca. $56 \%$ and $65 \%$ after $24 \mathrm{~h}$, and $65 \%$ and $63 \%$ after $48 \mathrm{~h}$ of preparing the spore suspension from the culture growing under moderate and sublethal Cd stress, respectively (Figure 1C).
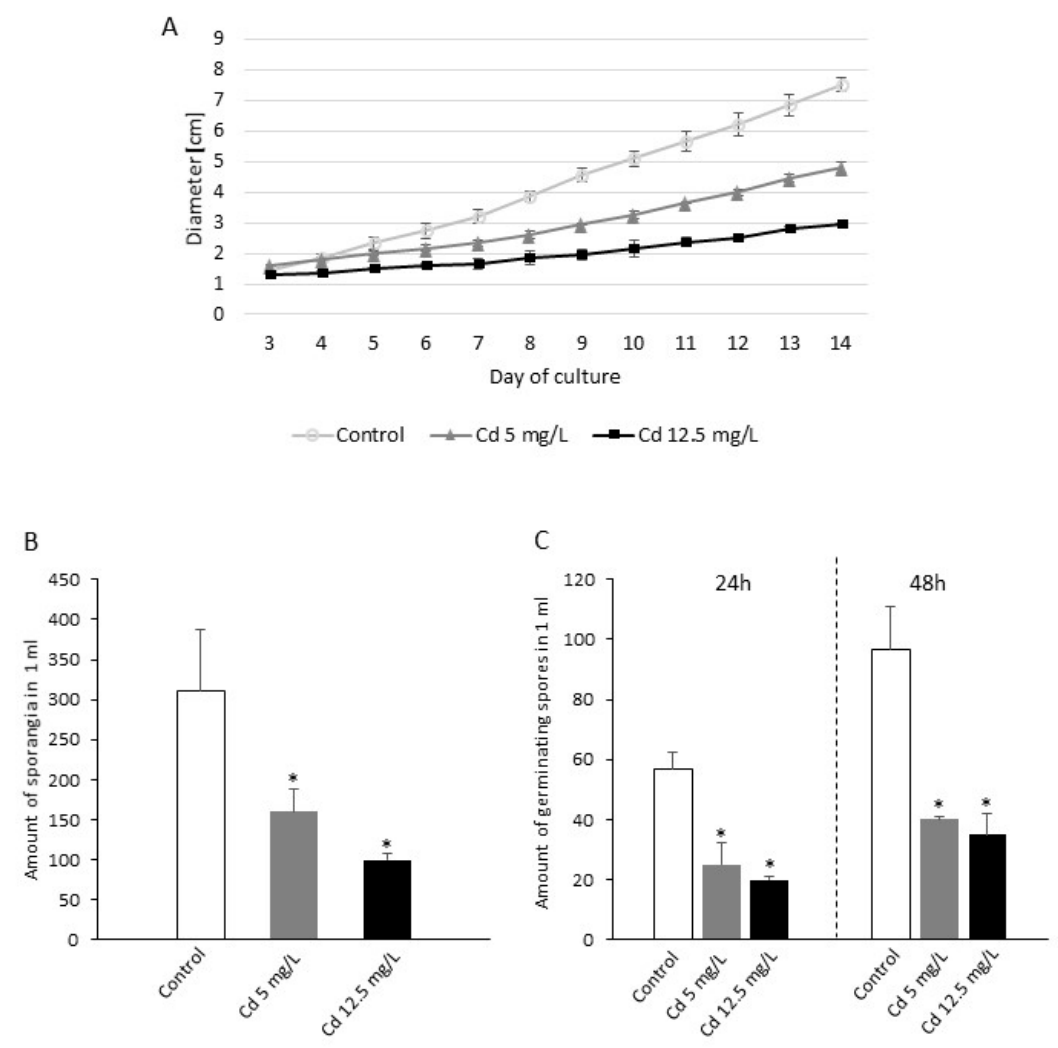

Figure 1. The effect of various $\mathrm{Cd}$ concentrations on Phytophthora infestans in vitro growth and sporulation. (A) Radial growth of $P$. infestans on medium supplemented with 0,5 , and $12.5 \mathrm{mg} / \mathrm{L}$ of Cd; (B) amount of sporangia formation in P. infestans culture treated with 0,5 , and $12.5 \mathrm{mg} / \mathrm{L}$ of Cd; (C) amount of germinating spores determined following a 24 and 48-h exposure to Cd stress. The results are an average from three independent experiments \pm SD. Asterisks indicate values that differ significantly from the nontreated (control) P. infestans culture at $p<0.01\left(^{*}\right)$. 
2.2. Cadmium Exposure Provokes Reactive Oxygen and Nitrogen Species Formation in P. infestans Structures

The observed inhibition of $P$. infestans in vitro growth was accompanied by marked changes in nitro-oxidative metabolism in $P$. infestans structures. Both $\mathrm{Cd}$ concentrations caused a significant increase in superoxide anion $\left(\mathrm{O}_{2}^{-}\right)$levels. The lower $\mathrm{Cd}$ dose caused a ca. 2-fold increase, while the higher one provoked only ca. $43 \%$ rise in $\mathrm{O}_{2}{ }^{-}$accumulation in comparison to the control culture of $P$. infestans (Figure 2A). Cadmium stress resulted also in a statistically insignificant drop in hydrogen peroxide $\left(\mathrm{H}_{2} \mathrm{O}_{2}\right)$ formation (Figure 2B).
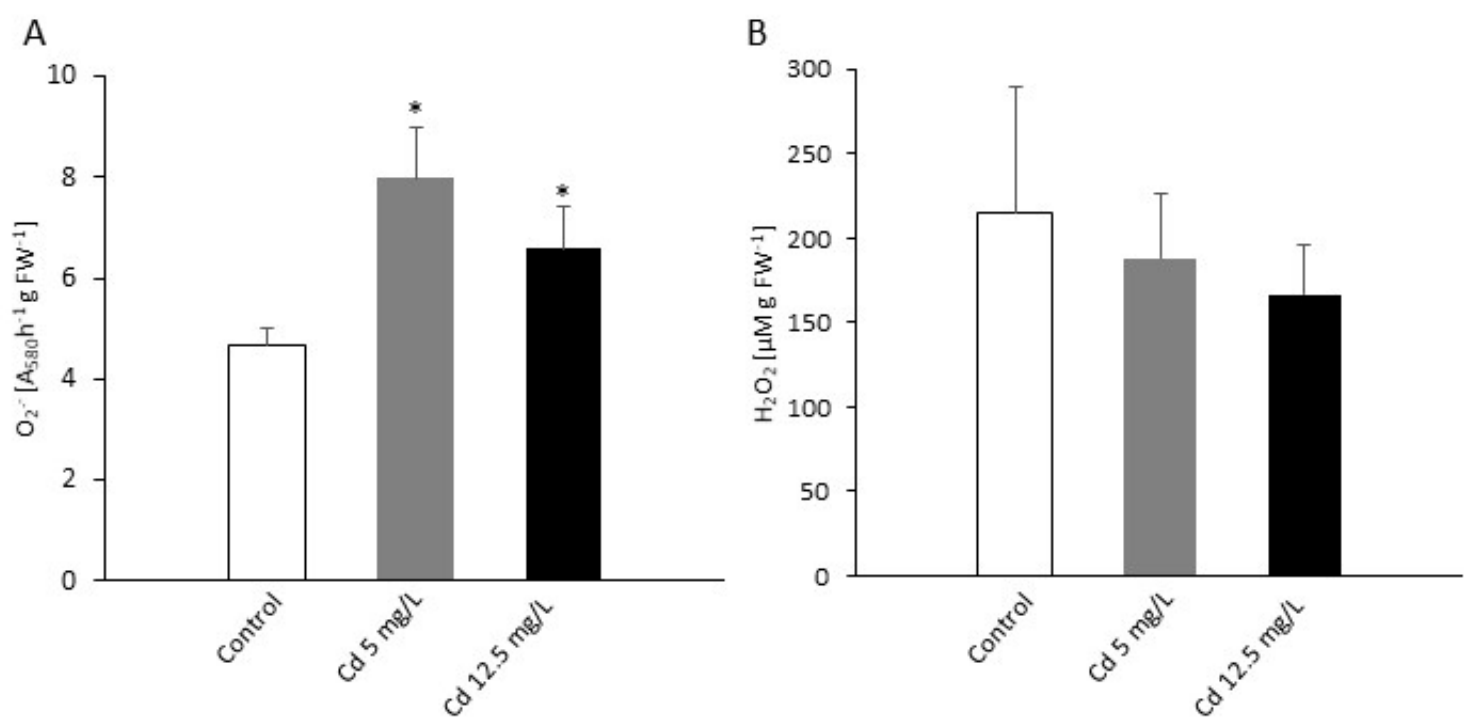

Figure 2. The effect of $\mathrm{Cd}$ on reactive oxygen species formation in P. infestans. (A) Superoxide radical and (B) hydrogen peroxide production at 14th day of the culture exposed to Cd stress. The results are an average from three independent experiments \pm SD. Asterisks indicate values that differ significantly from the nontreated (control) P. infestans culture at $p<0.01\left(^{*}\right)$.

Measurement of NO using a fluorescent indicator DAF-2DA (4,5-diaminofluorescein diacetate) revealed enhanced generation of this RNS in P. infestans structures growing in vitro in the presence of $\mathrm{Cd}$. Hyphae exposure to the moderate $\mathrm{Cd}$ dose resulted in an over two-fold increase of $\mathrm{NO}$ production; in turn, sublethal heavy metal stress provoked a huge overproduction of NO localized in hyphae and sporangia of the pathogen. Moreover, application of cPTIO (2-phenyl-4,4,5,5,tetramethylimidazoline-1-oxyl 3-oxide) as a specific NO scavenger resulted in a highly reduced NO-dependent fluorescence, confirming specificity of NO formation in P. infestans structures after Cd challenge (Figure 3A,B). Pathogen exposure to both $\mathrm{Cd}$ stresses triggered also a ca. $30 \%$ rise in peroxynitrite $\left(\mathrm{ONOO}^{-}\right)$formation (Figure $\left.3 \mathrm{C}\right)$.

\subsection{Cadmium Affects the Nitro-Oxidative Pattern of Nucleic Acids and Proteins}

To verify that Cd-mediated RNS formation is able to provoke nitration at the RNA and DNA levels in the P. infestans cellular environment, the accumulation of $8-\mathrm{NO}_{2}-\mathrm{G}$ was monitored as a marker of nucleic acid nitration (Figure 4). As had been expected, the heavy metal presence resulted in $8-\mathrm{NO}_{2}-\mathrm{G}$ overaccumulation within both the RNA and DNA pools. However, only a sublethal Cd dose provoked a statistically significant, ca. 4-fold increase of 8- $\mathrm{NO}_{2}$-G RNA accumulation in relation to the control (Figure 4A). A similar, Cd dose-dependent trend was observed in nitrated DNA. Briefly, a definitely higher level, ca. 6-fold rise of 8- $\mathrm{NO}_{2}$-G DNA was noted in pathogen structures exposed to sublethal Cd stress (Figure 4B). 
A

Control

$\mathrm{Cd} 5 \mathrm{mg} / \mathrm{L}$

$\mathrm{Cd} 12.5 \mathrm{mg} / \mathrm{L}$
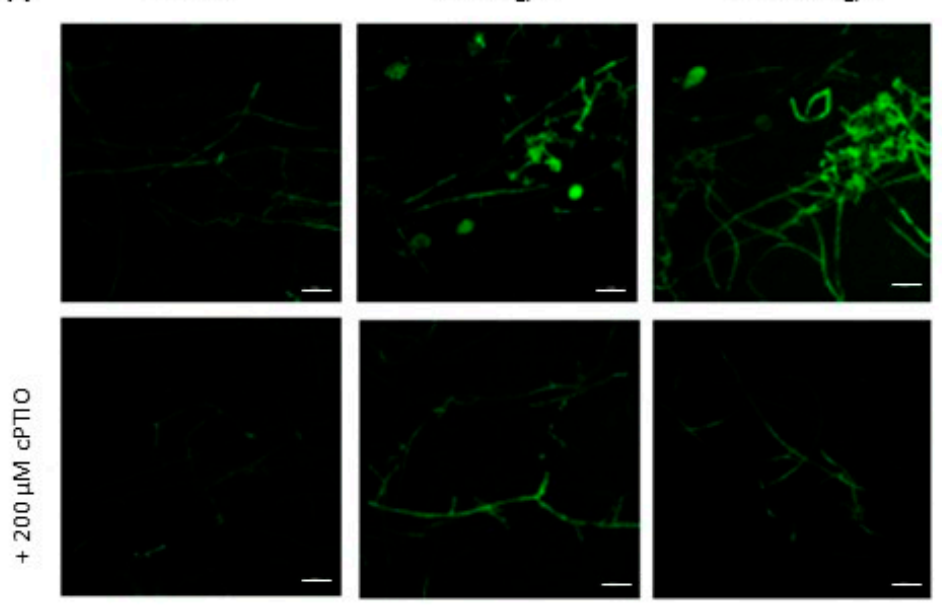

B
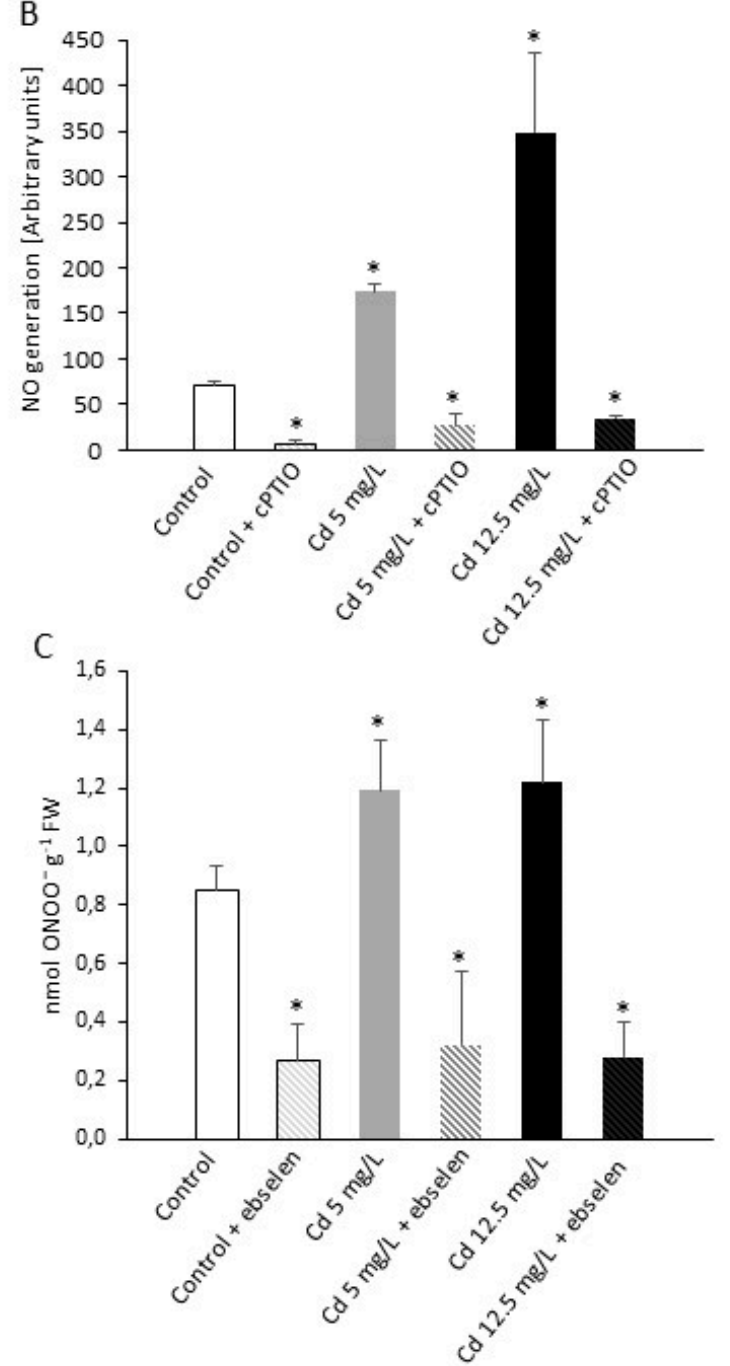

Figure 3. Bio-imaging of NO with DAF-2DA (4,5-diaminofluorescein diacetate) in P. infestans structures growing under Cd stress. (A,B) Nitric oxide was analyzed at 14 th day of the culture growing in the presence of 0,5 , and $12.5 \mathrm{mg} / \mathrm{L}$ of Cd $\pm 200 \mu \mathrm{M}$ cPTIO (2-phenyl-4,4,5,5,-tetramethylimidazoline-1-oxyl 3-oxide). Bars indicate $50 \mu \mathrm{m}$. Images show general phenomena representative of three independent experiments. (C) Peroxynitrite content in P. infestans at 14th day of the culture growing under Cd stress. The results are an average from three independent experiments \pm SD. Asterisks indicate values that differ significantly from the nontreated (control) $P$. infestans culture at $p<0.01\left(^{*}\right)$. 

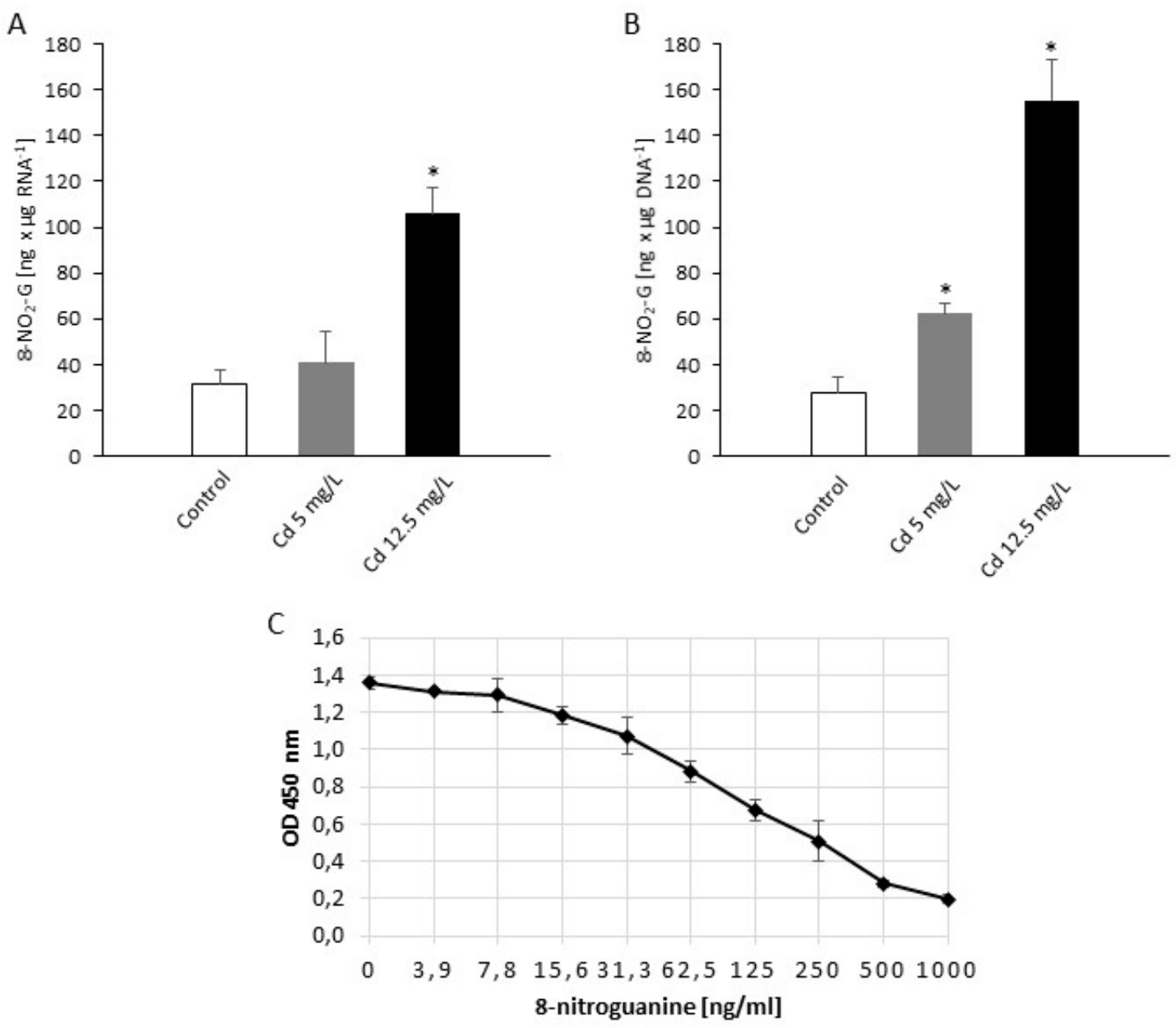

Figure 4. RNA and DNA nitration in P. infestans at 14th day of the culture exposed to Cd stress. (A) Quantification of nitrated RNA measured as 8- $\mathrm{NO}_{2}-\mathrm{G}$ content; (B) quantification of nitrated DNA measured as 8- $\mathrm{NO}_{2}-\mathrm{G}$ content; (C) 8-nitroguanine ELISA standard curve in the concentration range of $0-1000 \mathrm{ng} / \mathrm{mL}$. The results are an average from three independent experiments $\pm \mathrm{SD}$. Asterisks indicate values that differ significantly from the nontreated (control) $P$. infestans culture at $p<0.01\left(^{*}\right)$.

An opposite effect was observed in relation to the protein pool undergoing nitration and oxidation as a consequence of Cd-induced RNS/ROS formation. A total amount of nitrated proteins was ca. $25 \%$ lower in P. infestans structures growing under moderate Cd stress; in turn, the higher Cd concentration provoked only ca. $15 \%$ increase in the pool of nitrated proteins when compared to the control (Figure 5A). A significant difference between moderate and sublethal Cd stresses was noted also in the case of protein carbonylation. While at the lower $\mathrm{Cd}$ concentration a slight decrease (ca. $10 \%)$ in protein carbonylation was noted, the higher metal dose increased this type of protein oxidation by as much as over $30 \%$ (Figure $5 \mathrm{~B}$ ).

\subsection{Cadmium Accelerates P. infestans Antioxidative Response}

To determine the effect of $\mathrm{Cd}$ stress on the vr $P$. infestans antioxidant system, total antioxidative capacity (TAC), transcript accumulation, and biological activity of the key antioxidant enzymes, i.e., catalase (CAT) and superoxide dismutase (SOD), were evaluated (Figure 6). 
A

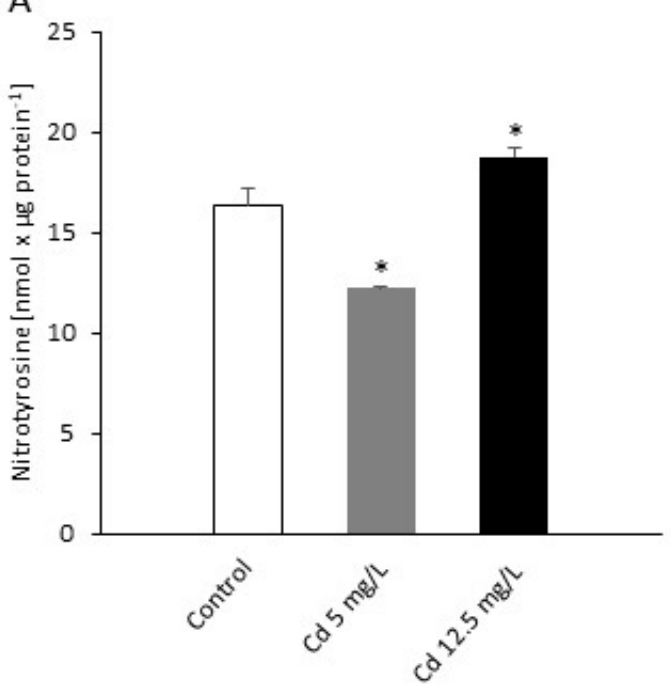

B

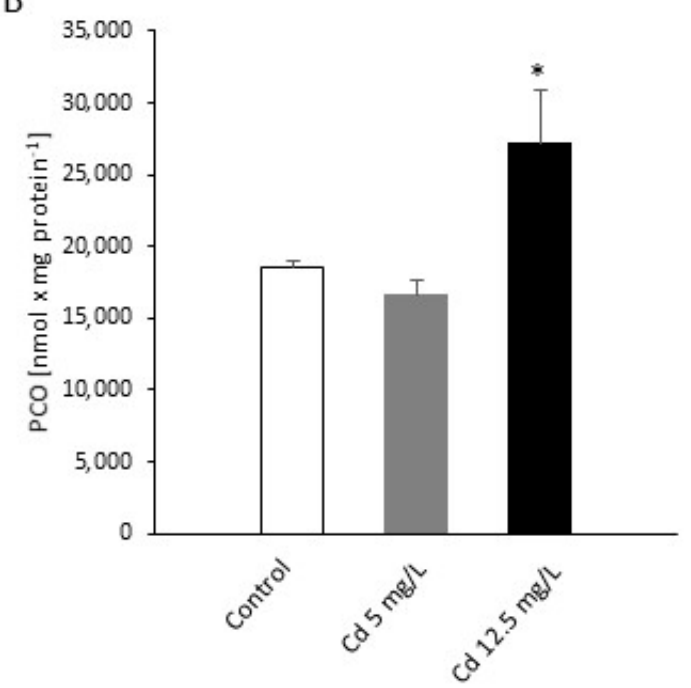

Figure 5. Protein nitration and carbonylation in P. infestans at 14th day of the culture exposed to Cd stress. (A) Quantification of nitrated proteins measured as nitrotyrosine content; (B) content of carbonylated proteins. The results are an average from three independent experiments $\pm \mathrm{SD}$. Asterisks indicate values that differ significantly from the nontreated (control) P. infestans culture at $p<0.01\left(^{*}\right.$ ).

The Cd provoked changes in ROS/RNS metabolism in P. infestans structures were accompanied by an enhanced content of the so-called fast antioxidants, including the reduced pool of ascorbate and glutathione; however, the highest level was noted under moderate $\mathrm{Cd}$ stress conditions (Figure 6A). An opposite effect was observed in the case of the so-called slow antioxidants involving e.g., residues of tyrosine and tryptophan in proteins; briefly, the pool of these antioxidants decreased by ca. $60 \%$ and $30 \%$ in response to moderate and sublethal $\mathrm{Cd}$ dose exposure, respectively (Figure 6B).

The expression analysis of the genes encoding selected antioxidant enzymes clearly indicated that moderate $\mathrm{Cd}$ stress effectively increased transcription of SOD1, which product is responsible for scavenging the superoxide anion radical (Figure S2, Figure 6C). RT-qPCR assays of SOD1 showed that $5 \mathrm{mg} / \mathrm{L}$ of $\mathrm{Cd}$ provoked a ca. 5-fold increase of the gene expression. An opposite effect was observed at the highest $\mathrm{Cd}$ concentration $(12.5 \mathrm{mg} / \mathrm{L})$, since a decreased SOD1 expression in comparison to the control was noted. The activity of SOD was accelerated at both $\mathrm{Cd}$ concentrations. Although a ca. 2-fold and 2.5-fold rise of the enzyme activity was found in response to moderate and sublethal $\mathrm{Cd}$ doses, respectively (Figure 6E), the SOD isoenzyme pattern detected in P. infestans growing under Cd stress was reduced from 8 to 5 protein bands described as nos. 3, 4, 5, 7, and 8 (Figure 6G, Figure S3).

Although heavy metal stress significantly diminished CAT gene expression (Figure 6D), an over 4-fold increase of CAT activity was observed in vr P. infestans growing at the lower Cd concentration (Figure 6F). Simultaneously, two CAT isoforms appeared in response to $\mathrm{Cd}$ stress; however, the Cd-responsive CAT protein band (no. 1) was more visible in extracts obtained from vr P. infestans structures exposed to moderate $\mathrm{Cd}$ stress (Figure 6H, Figure $\mathrm{S4}$ ). 

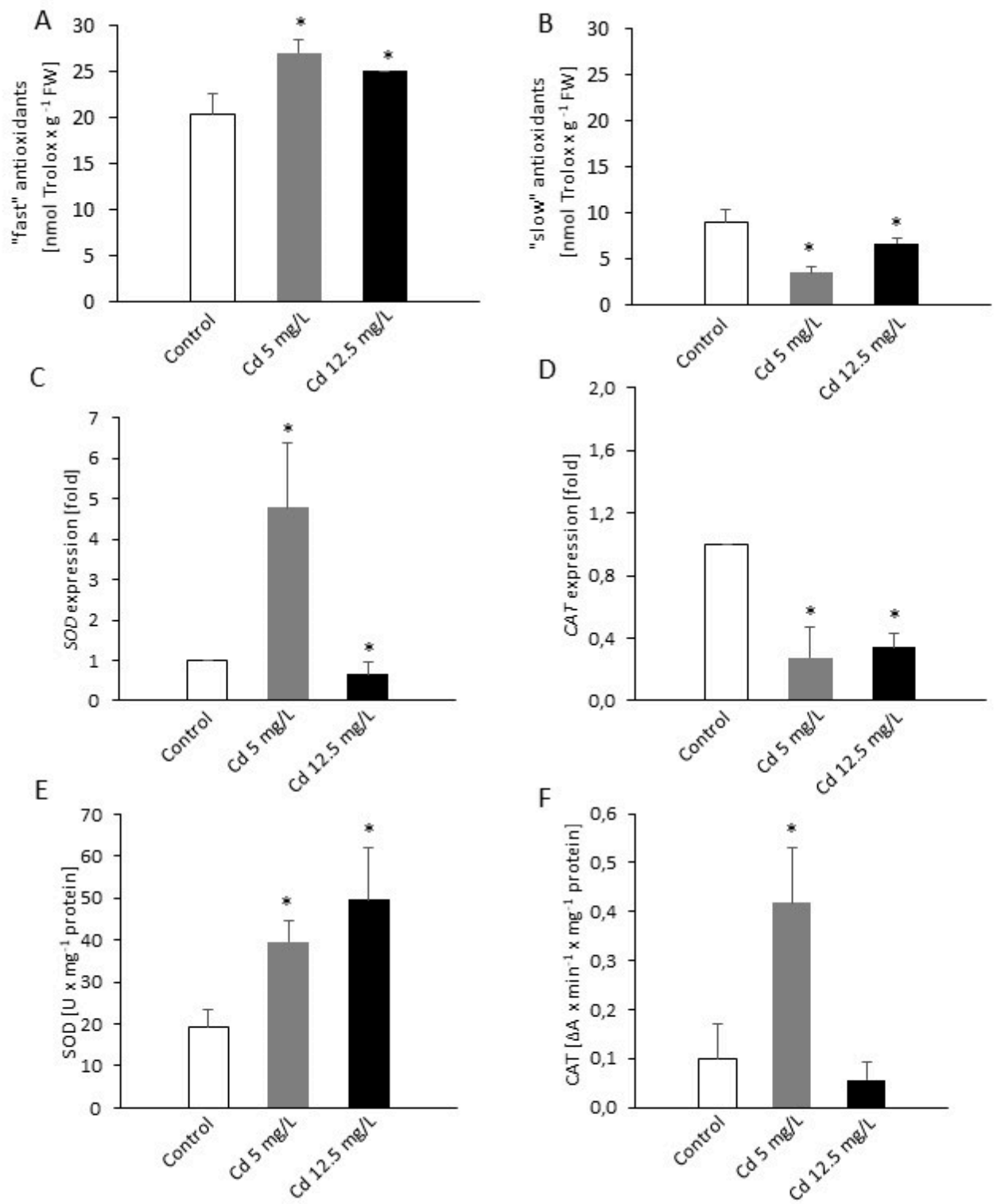

$\mathrm{F}$

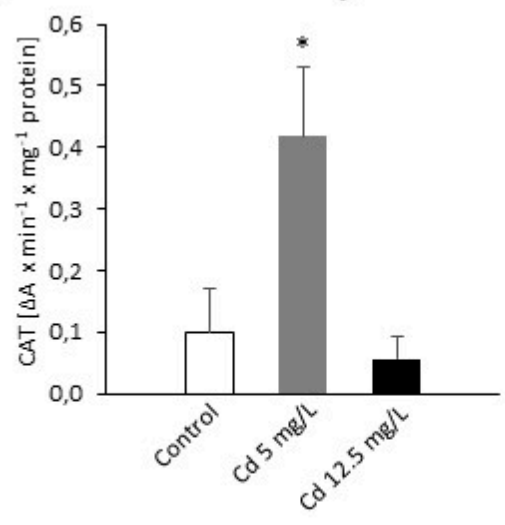

G

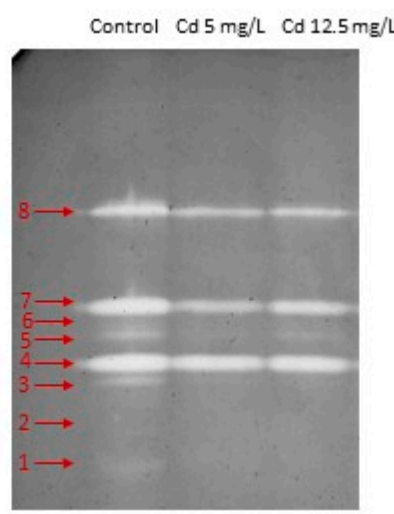

$\mathrm{H}$

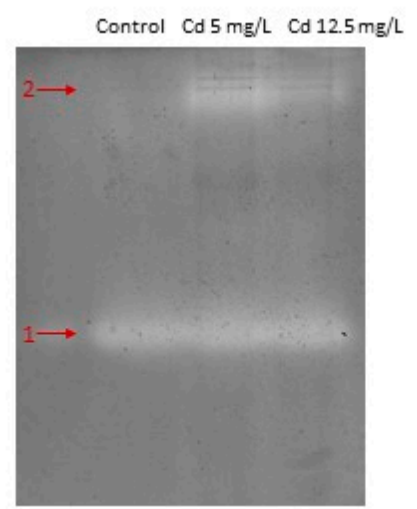

Figure 6. The effect of $\mathrm{Cd}$ on the selected elements of the antioxidant system in P. infestans. A total antioxidant capacity of P. infestans: (A) the content of "fast" and (B) "slow" antioxidants; RT-qPCR analysis of (C) SOD (superoxide dismutase) and (D) CAT (catalase) genes expression; the activity of (E) SOD and (F) CAT. The results are an average from three independent experiments \pm SD; asterisks indicate values that differ significantly from the nontreated (control) P. infestans culture at $p<0.01\left(^{*}\right.$ ). Representative images of isoenzyme patterns of $(\mathbf{G})$ SOD and (H) CAT in P. infestans structures at 14th day of the culture growing under Cd stress. 


\subsection{Moderate Cadmium Stress Amplifies P. infestans Pathogenicity on Potato}

To assess if $\mathrm{Cd}$ stress affects vr $P$. infestans aggressiveness, potato leaves were inoculated with the spore suspension prepared from hyphae growing under moderate $\mathrm{Cd}$ stress $(5 \mathrm{mg} / \mathrm{L})$. For the experiment three cultivars of potato were used, i.e., Bintje (Bi), Bzura (Bz), and Sarpo Mira (SM). The highest infection rate after inoculation with vr P. infestans growing on the control medium showed cv. Bintje, since disease spots covered $50 \%$ of Bintje leaf area at 7 th day post inoculation (dpi). In turn, cv. Bzura and Sarpo Mira exhibited disease symptoms on $30 \%$ and $10 \%$ of leaf area, respectively (Figure 7A). When the used potato cultivars were inoculated with vr P. infestans spore suspension prepared from the culture growing under moderate $\mathrm{Cd}$ stress, significant changes in the rate of late blight development were observed. Disease symptoms at 7 th dpi covered a much larger area of the leaves in cultivars Bintje and Bzura when compared to leaves inoculated with $P$. infestans growing under the control conditions (Figure 7B). Based on the disease index, inoculation with the Cd-stressed pathogen provoked late blight symptoms covering ca. $90 \%$ of 'Bintje' leaf area, 50\% of 'Bzura' leaf area, and $10 \%$ of 'Sarpo Mira' leaf area, respectively (Figure 7C).

A

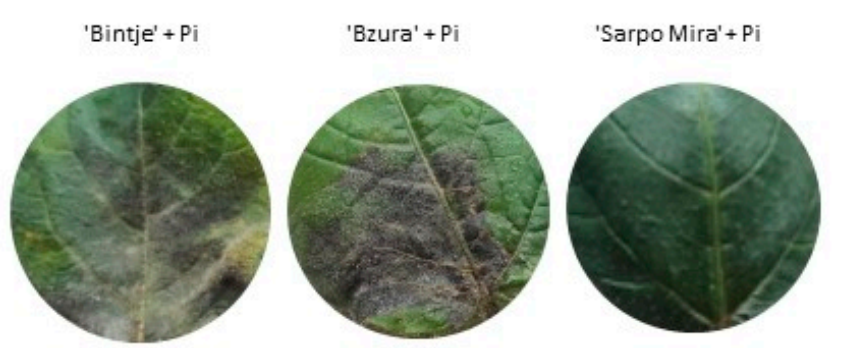

B
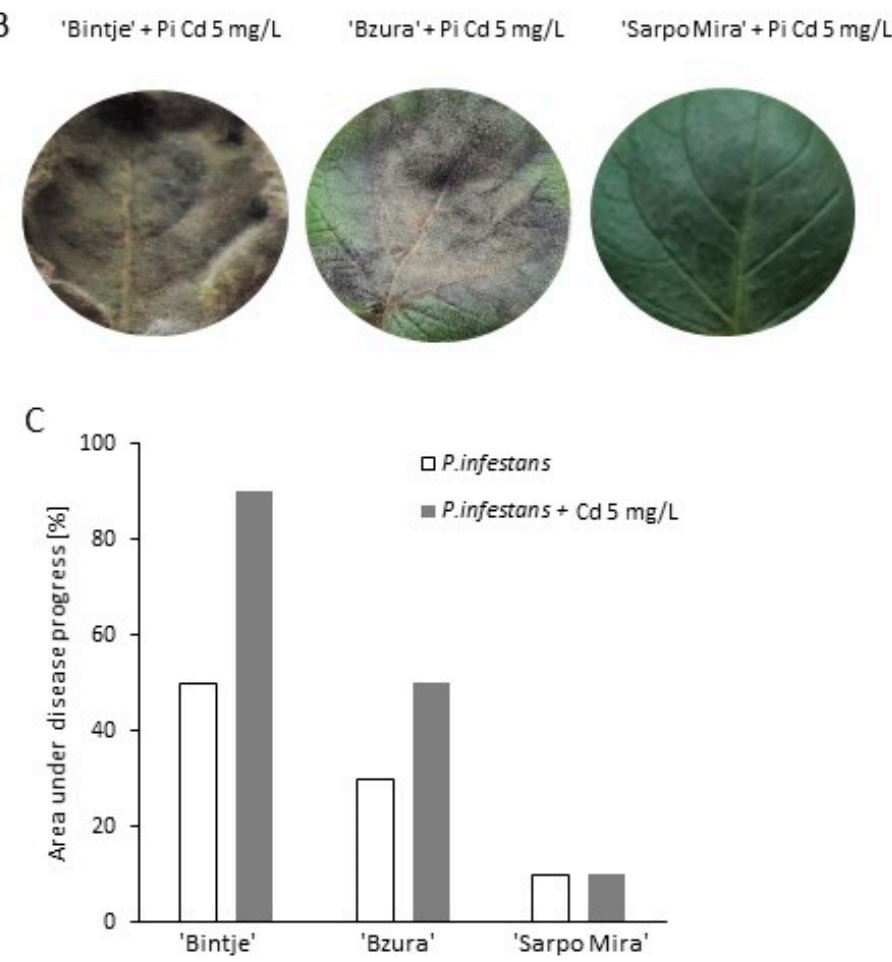

Figure 7. The effect of moderate cadmium stress on $P$. infestans aggressiveness. Representative images of leaves of three potato cultivars inoculated with vr P. infestans (A) growing in the absence of $\mathrm{Cd}$ (control media) and (B) in the media supplemented with Cd $5 \mathrm{mg} / \mathrm{L}$; (C) the comparison of late blight disease development on the leaves of three potato cultivars inoculated with $\mathrm{vr} P$. infestans growing on a medium without and with $\mathrm{Cd} 5 \mathrm{mg} / \mathrm{L}$. 
The rate of $P$. infestans infection was also quantified by RT-qPCR. The transcript level of the Pitef1 gene was calculated relative to the expression level of the potato Ef1- $\alpha$ gene according to Orłowska et al. [35]. In general, addition of $\mathrm{Cd}(5 \mathrm{mg} / \mathrm{L})$ to the growing medium of vr P. infestans provoked an enhanced expression of Ptef1 under in planta conditions in comparison to leaf inoculation with vr P. infestans growing in the control medium (Figure 8). The Pitef1 gene expression started to increase from the 6th hour post inoculation (hpi) in Bi leaves and the highest transcript accumulation, i.e., an over 95-fold rise, was noted at $72 \mathrm{hpi}$ (Figure 8A). A similar Cd-mediated effect was observed during the Bz-vr P. infestans interaction and a ca. 10-fold increase of the transcript accumulation was noted at 48 and 72 hpi (Figure 8B). Cadmium stress elevated expression of Pitef1 in planta also during the pathogen interaction with the SM genotype. The gene expression started to increase from $24 \mathrm{hpi}$ in SM leaves and an over 3-fold increase was noted at 48 and 72 hpi (Figure 8C).
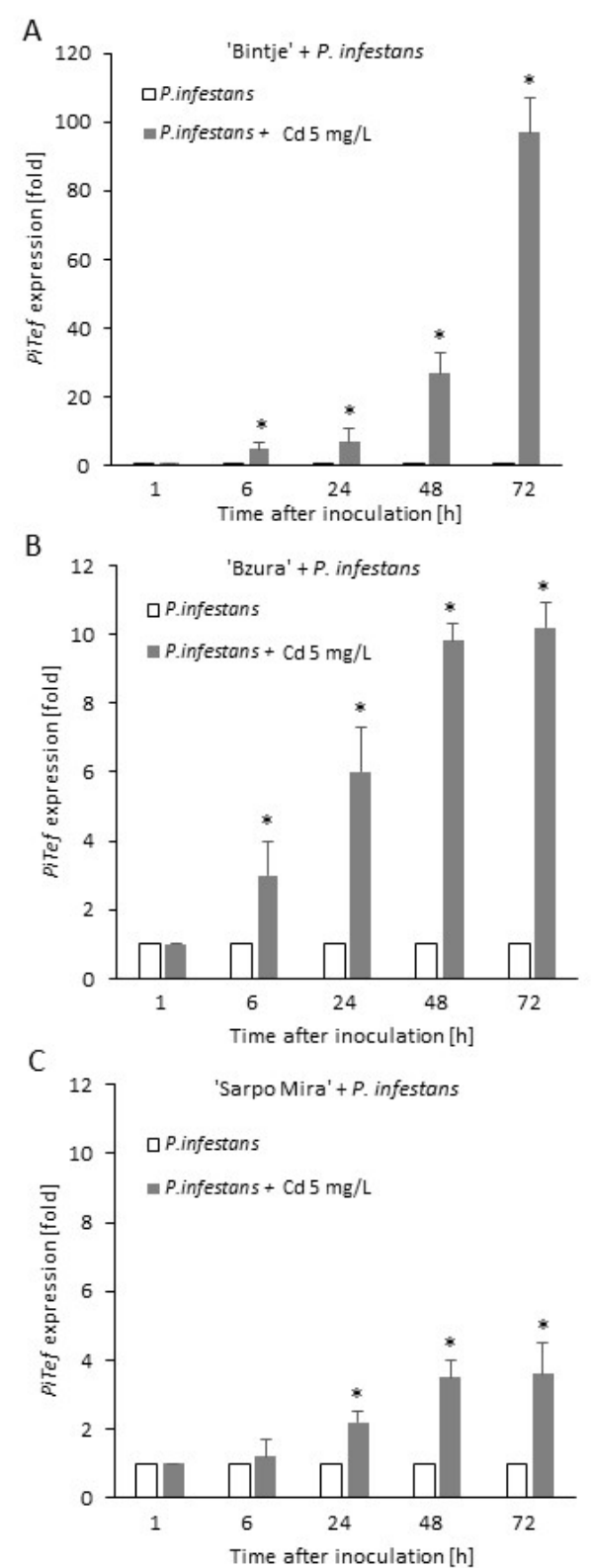

Figure 8. Expression analysis of the Phytophthora infestans Tef1 gene (PiTef1) in leaves of three potato cultivas (A) Bintje, (B) Bzura, (C) Sarpo Mira inoculated with vr P. infestans growing in the absence of $\mathrm{Cd}$ (control media) and in the media supplemented with $\mathrm{Cd} 5 \mathrm{mg} / \mathrm{L}$. The values are normalized to the potato Ef1- $\alpha$ gene. The results are an average from three independent experiments \pm SD. Asterisks indicate values that differ significantly from the nontreated $P$. infestans inoculated leaves at $p<0.01\left(^{*}\right)$. 


\section{Discussion}

No comprehensive studies are available on the effects of nonessential toxic metals on biology and pathobiology of plant pathogens. However, there is a growing body of evidence suggesting a link between heavy metal stress and modification of microorganism pathogenicity [36,37].

The presented study clearly indicates that $C d$ stress affects in vitro growth of the oomycete plant pathogen $P$. infestans. The higher the metal concentration applied, the greater reduction was observed in radial growth of vr MP 977 P. infestans hyphae. The most adverse effect was provoked by Cd at the concentration of $12.5 \mathrm{mg} / \mathrm{L}$ reflecting the sublethal Cd dose. It was earlier found that some plant pathogens belonging to oomycetes, e.g., Pythium debaryanum, can exhibit a high degree of tolerance to heavy metals, since it can grow in the presence of high metal doses including $100 \mathrm{mg} / \mathrm{L} \mathrm{of} \mathrm{Cd}$, $\mathrm{Pb}, \mathrm{Cu}$, and $\mathrm{Zn}$. What is more, a low $\mathrm{Pb}$ concentration $(3 \mathrm{mg} / \mathrm{L})$ even stimulated the growth rate of P. debaryanum [19]. Lorenzo-Gutiérrez et al. [38] underlined that some soil microorganisms may exhibit a high tolerance to heavy metals, probably acquired through their evolutionary adaptation to contaminated environments. Therefore, the survival of fungal or fungal-like cultures should not be surprising, even at metal doses that are lethal for organisms belonging to distant systematic groups.

In general, heavy metals can affect morphogenesis of the vegetative hyphae or mycelium as well as sexual and asexual reproduction. The Cd-reduced growth of vr MP 977 P. infestans culture was accompanied by low sporangia abundance with a delayed germination rate. A similar effect was observed earlier in the oomycete Dictyuchus carpophorus treated even with low concentrations of $\mathrm{Cd}$ [24]. Heavy metals at concentrations of $0.5-1.0 \mathrm{mM} \mathrm{Cu}, \mathrm{Cr}$, and $\mathrm{Hg}$ were also able to inhibit hyphae growth and sporulation in the oomycete Phytophthora capsici [25]. According to Gill [39] the reduced growth rate of pathogen hyphae in the presence of $\mathrm{Cd}$ may be a result of $\mathrm{Cd}$ interfering with the uptake, transport, and use of several elements $(\mathrm{Ca}, \mathrm{Mg}, \mathrm{P}$, and $\mathrm{K})$ as well as water by the microorganism.

It is well known that even low concentrations of $\mathrm{Cd}$ as an environmental pollutant provoke cell redox misbalance manifested by ROS/RNS overproduction, which may contribute to the metal toxicity [25]. As earlier documented, in vitro growth of the vr MP 977 P. infestans is accompanied by RNS formation and it is accelerated during in planta sporangia development [31]. In the present study we found that $\mathrm{Cd}$ stress boosted NO formation in both sporangia and hyphae under in vitro conditions. Since RNS could mediate nuclear division or degeneration of a proportion of the nuclei in the sporangium providing sporangia with the ability to release zoospores in rapid succession [31], the sporangia-localized NO overproduction in response to heavy metal stress seems to be essential for pathogen survival. Moreover, NO can accelerate formation and maturation of asexual reproductive structures by controlling the expression of the conidiation related con genes [40].

It is important to note that $\mathrm{NO}$ overproduction noted in P. infestans structures growing under $\mathrm{Cd}$ stress was orchestrated with superoxide elevation, favoring a microenvironment for $\mathrm{ONOO}^{-}$ formation. However, both moderate and sublethal stresses boosted $\mathrm{ONOO}^{-}$formation in the same extent. Further insight into the cellular redox status of $P$. infestans exposed to heavy metal stress revealed that RNS overproduction is accompanied by nitro-oxidative modifications of the key biomolecules including proteins and nucleic acids. Although protein nitration is still perceived as a marker of nitro-oxidative stress, our results suggest that this modification acts as a physiological regulator to dynamically redirected cellular metabolism under environmental disorders. Moderate Cd stress diminished the pool of nitrated proteins, whereas the sublethal one only slightly increased the nitrated protein level in comparison to the control. A slight fluctuation within the nitrated protein pool was also observed earlier in vr MP 977 P. infestans structures during in planta growth despite the host's nitro-oxidative environment favoring biomolecule modification [31]. Thus, changes in the protein pool undergoing Tyr nitration phenomena in P. infestans may reflect a homeostasis misbalance connected with the adaptation strategy of the microorganism to different microenvironments, including the host or heavy metal contamination.

Cadmium-provoked nitrative modification in vr MP 977 P. infestans structures involved also nucleotides in DNA and RNA. The formation of 8-nitroguanine occurred to a much greater extent 
under the sublethal $\mathrm{Cd}$ dose, indicating that these DNA/RNA lesions can contribute to the metal toxicity. Although this statement is in line with human/animal models where the occurrence of nitrated nucleic acids has been regarded as a marker of pathogenesis and damage, recent findings in plant models suggest that the nitrative modification of RNA may function as a smart redox switch of gene expression [41]. A functional consequence of posttranscriptional mRNA modifications consists in hampered translation, resulting in a decreased level of encoded proteins or even expanding the diversity of proteins through recoding [42]. Importantly, quantification of nitrated RNA measured as the 8- $\mathrm{NO}_{2}-\mathrm{G}$ content in vr MP 977 P. infestans showed no statistically significant increase of this modification at moderate Cd stress, suggesting a scenario that RNA nitrative modification might function as a swift adjustment of $P$. infestans metabolism under abiotic stimuli rather than merely nitrative damage of RNA. Certainly future identification of mRNA nitration targets will provide a verification of these assumptions.

To cope with metal toxicity, microorganisms activate antioxidant systems [43]. In phytopathogens induction of antioxidant enzymes in response to the heavy metal mediated oxidative stress has been demonstrated in a fungus P. chrysosporium [44] and an oomycete Phytophthora capsici [25]. The antioxidant response of $P$. infestans engaged transcriptional, post-translation, and enzymatic machinery, which facilitates adaptation to the nitro-oxidative environment provoked by $\mathrm{Cd}$. Although a number of genes whose products are potentially involved in maintaining cell redox balance (SOD1, PiCAT5, CATG, GPX2, PiPRX2, and PiTPX2) have been studied in vr MP 977 P. infestans, only SOD1, GPX2, and PiTPX2 were dose-dependently upregulated by $\mathrm{Cd}$ in the pathogen structures (Figure 6C, Figure S2). The obtained results clearly showed that the oomycete exposed to moderate Cd stress activates primarily SOD at both transcript and enzyme activity levels to cope with the Cd-induced oxidative stress; however, native electrophoresis revealed that $\mathrm{Cd}$ stress affects some SOD isoforms. These results are in line with the study of Ighodaro and Akinloye [45] indicating SOD as the first detoxification enzyme and the most powerful antioxidant within the cell exposed to ROS. Moreover, a high SOD expression at transcript and activity levels in vr MP 977 P. infestans may balance ONOOformation directly responsible for nitrative biomolecule modification.

Catalase may also play an important role in adaptation and ultimate survival of $P$. infestans during periods of stress and stress-induced ROS over-accumulation. In confirmation, the Cd-responsive CAT isoform correlated with an enhanced enzyme activity was detected only in P. infestans exposed to moderate Cd dose. A similar effect was observed in a fungus Phanerochaete chrysosporium, in which a lower $\mathrm{Cd}$ concentration or short-term $\mathrm{Cd}$ stress was effective in induction of CAT activity; in turn, larges $\mathrm{Cd}$ doses or longer stress exposure did not provoke the enzyme activity [46]. Both CAT and SOD activities were also elevated in yeast Trichosporon cutaneum treated with $\mathrm{Cd}$ and $\mathrm{Cu}$ and were indicated as key enzymes engaged in ROS scavenging in the fungus [22].

An ROS/RNS imbalance and enhanced antioxidant response noted in P. infestans structures growing under moderate $\mathrm{Cd}$ stress was also associated with an enhanced aggressiveness of the pathogen; however, it may be a metal dose-dependent phenomenon. Inoculation of potato leaves with the spore suspension prepared from vr $P$. infestans MP 977 culture growing in media supplemented with $\mathrm{Cd}(5 \mathrm{mg} / \mathrm{L})$ provoked accelerated disease symptoms on two potato cultivars, i.e., Bi and Bz. The rate of disease development measured as the disease index was not affected in the case of SM; however, molecular assessment of disease progress revealed a significantly higher Pitef gene expression under in planta condition starting from the first day after SM inoculation. These results clearly show that in all the analyzed interactions the rate of infection development was accelerated when spores were derived from the $\mathrm{Cd}$ stressed vr P. infestans culture. A well-known defense strategy of host organisms is to produce ROS to combat the pathogen. The ROS burst has been detected in many plant-pathogen interactions as an early event of the plant defence strategy, including the potato-P. infestans interaction [47]. Thus, an enhanced aggressiveness of $P$. infestans growing in the presence of $\mathrm{Cd}$ might be linked to the efficient elimination of host (potato)-derived ROS despite the fact that the $\mathrm{Cd}$ dose delayed germination of spores. More precisely, an enhanced aggressiveness of $P$. infestans may result from the Cd-activated antioxidant 
system, i.e., SOD and CAT. Notably, cytosolic $\mathrm{Cu} / \mathrm{Zn}$ Sod1 was documented as a virulence factor for Cryptococcus neoformans and Candida albicans. In turn, in a human pathogen Aspergillus fumigatus all SODs were required for full virulence of the pathogen [48]. Interestingly, the heavy metal-induced expression of $P c a A$, a cation ATPase, was proved to provide $C d$ tolerance in A. fumigatus and support its virulence in the Galleria mellonella model [34]. As the authors stated, an increased PcaA protein level favors ROS detoxification in A. fumigatus protecting the microorganism against both Cd-mediated and host-derived oxidative stress. Importantly, the protection capacity of Cd-induced metabolic events to subsequent stress was demonstrated earlier in plants. As documented Stroiński et al. $[49,50] \mathrm{Cd}$ was able to induce cross-resistance phenomenon of potato to $P$. infestans since tubers and leaves of susceptible potato $\mathrm{cv}$. Bi exposed to the heavy metal showed induction of basal defense and reduced symptoms of late blight disease.

Concluding, $\mathrm{Cd}$ stress not only inhibited cellular growth and caused biochemical changes in vr $P$. infestans, but it also favored pathogenicity of the oomycete. The presented results shed new light on the mechanism, showing that the nitro-oxidative homeostasis imbalance underlies a link between heavy metal stress and modification of microorganism pathogenicity. However, whether the nature of the observed phenomenon of an enhanced aggressiveness of $P$. infestans underlies stress cross-protection, observed earlier in yeast cells [51] and/or involves epigenetic mechanisms and transcriptional reprogramming of pathogenicity related genes will require future experimental verification.

\section{Materials and Methods}

\subsection{Pathogen Culture}

Phytophthora infestans, a virulent race 1.2.3.4.6.7.10 (MP 977) was supplied by the Plant Breeding and Acclimatization Institute, (IHAR) Research Division at Młochów, Poland. The pathogen was cultured for 14 days at $16{ }^{\circ} \mathrm{C}$ in the dark on a cereal-potato medium prepared by single components with the addition of dextrose (Sigma; Saint-Louis, MO, USA). For in planta experiments potato leaves were inoculated by spraying with the zoospore suspension at a concentration of $2.5 \times 10^{5}$ per $1 \mathrm{~mL}$ of water as described by Arasimowicz-Jelonek et al. [52] and then leaves were kept at $16{ }^{\circ} \mathrm{C}$ and $95 \%$ humidity.

\subsection{Plant Material}

Plants of three potato cultivars Bintje, Bzura and Sarpo Mira came from the Potato Gene Bank (Plant Breeding and Acclimatization Institute-IHAR in Bonin, Bonin, Poland). Potato seedlings propagated through in vitro culture were transferred to the soil and kept in a phytochamber with $16 \mathrm{~h}$ of light $\left(180 \mu \mathrm{mol} \cdot \mathrm{m}^{-2} \cdot \mathrm{s}^{-1}\right)$ at $18 \pm 2{ }^{\circ} \mathrm{C}$ and $40 \%$ humidity up to the stage of 10 leaves.

\subsection{Assessment of the Area under Disease Progress}

In order to estimate the development of disease symptoms, percentage of the leaf area under disease progress $(n=15)$ was evaluated after 7 days from spraying the leaves with a P. infestans spore suspension $\left(2.5 \times 10^{5}\right.$ per $\left.1 \mathrm{~mL}\right)$ prepared from hyphae growing in the absence of $\mathrm{Cd}$ (control media) and the media supplemented with $\mathrm{Cd} 5 \mathrm{mg} / \mathrm{L}$.

\subsection{Cadmium Stress, Hyphal Growth, and Sporulation of P. infestans}

The heavy metal $\left(\mathrm{Cd}^{2+}\right)$ stock solution was obtained from its chlorine salt (P.O.Ch.; Gliwice, Poland; grade min. 99.5\%) that was dissolved in sterilized water. For in vitro growth experiments the stock solution was added to the growing medium to reach the following concentrations of Cd: $0,1,2.5,5,12.5$, and $25 \mathrm{mg} / \mathrm{L}$. Two Cd concentrations, i.e., 5 and $12.5 \mathrm{mg} / \mathrm{L}$ reflecting moderate and sublethal heavy metal stress, respectively, were selected for further analyses. Material for molecular and biochemical analyses was collected on the 14th day of the culture. 
Radial growth of $P$. infestans was measured every day for a period of 14 days-the time of pathogen culture. The spore suspension for the calculation of sporangia and germinating spore counts was freshly prepared from the control or Cd-exposed hyphae and the number of sporangia were determined using the Bürker chamber. To assess the number of germinating spores, microscopic counting was performed using $1 \%$ agar.

\subsection{Superoxide Radical Production}

Superoxide radical anion $\left(\mathrm{O}_{2}^{-}\right)$detection was performed using the method with nitroblue tetrazolium (NBT) described by Doke [53]. Briefly, hyphae $(0.05 \mathrm{~g})$ of $P$. infestans were incubated in $3 \mathrm{~mL}$ of incubation mixture (0.05\% NBT (SERVA; Heidelberg, Germany), $0.1 \mathrm{mM}$ EDTA (BioShop; Mainway, Burlington, ON, Canada), 0.065\% sodium azide (P.O.Ch.; Gliwice, Poland), and $50 \mathrm{mM}$ potassium phosphate buffer, pH 7.8 (Chempur; Piekary Ślaskie, Poland). The incubation mixture without the tested material was used as a blank sample. Samples were incubated in the dark at room temperature (RT) for $1 \mathrm{~h}$. After incubation $1.8 \mathrm{~mL}$ of the reaction mixture were heated at $85^{\circ} \mathrm{C}$ for $15 \mathrm{~min}$ to complete the reaction. After cooling on ice absorbance at a wavelength of $580 \mathrm{~nm}$ was determined by measuring the amount of reduced NBT to diformazane. Superoxide generation was expressed as the change in absorbance A580 per $1 \mathrm{~g}$ fresh weight (FW) per $1 \mathrm{~h}$.

\subsection{Hydrogen Peroxide Accumulation}

Hydrogen peroxide $\left(\mathrm{H}_{2} \mathrm{O}_{2}\right)$ concentration was assayed spectrophotometrically using the titanium $\left(\mathrm{Ti}^{4+}\right)$ method described by Becana et al. [54]. Hyphae (0.1 g) of P. infestans were homogenized in $1.6 \mathrm{~mL}$ of $0.1 \mathrm{M}$ potassium phosphate buffer ( $\mathrm{pH}$ 7.8) (Chempur; Piekary Ślaskie, Poland). After centrifugation $\left(13,000 \mathrm{~g}\right.$ for $25 \mathrm{~min}$ at $\left.4{ }^{\circ} \mathrm{C}\right)$ the supernatant was collected and used for assays. The reaction mixture $(1.5 \mathrm{~mL})$ contained $0.1 \mathrm{M}$ potassium phosphate buffer $(\mathrm{pH} 7.8)(600 \mu \mathrm{L})$, enzymatic extract $(400 \mu \mathrm{L})$, and titanium reagent $(500 \mu \mathrm{L})$. Titanium reagent was prepared on the day of the assay by mixing $0.6 \mathrm{mM}$ solution of 4-(2-pyridylazo) resorcinol (Sigma; Saint-Louis, MO, USA) and $0.6 \mathrm{mM}$ potassium titanium tartrate (Sigma; Saint-Louis, MO, USA) at a 1:1 ratio. The concentration of $\mathrm{H}_{2} \mathrm{O}_{2}$ was determined by measuring absorbance at a wavelength of $508 \mathrm{~nm}$ against a calibration curve and expressed as $\mu \mathrm{mol}$ $\mathrm{H}_{2} \mathrm{O}_{2}$ per $1 \mathrm{~g} F W$.

\subsection{Bio-Imaging of Nitric Oxide}

Nitric oxide in vivo formation was detected using DAF-2DA (4,5-diaminofluorescein diacetate) fluorochrome (Calbiochem; San Diego, California, U.S; excitation 495 nm; emission 515 nm). Briefly, P. infestans hyphae were incubated in the dark for $1 \mathrm{~h}$ in $10 \mathrm{mM}$ Tris-HCl buffer (pH 7.4) (Bio-Rad; Hercules, CA, USA) containing $10 \mu \mathrm{M}$ DAF-2DA. After incubation the mycelium was washed twice in $10 \mathrm{mM}$ Tris-HCl buffer ( $\mathrm{pH}$ 7.4) (Bio-Rad). Samples were examined under a Zeiss LSM 510 confocal microscope (Carl Zeiss, Jena, Germany) equipped with standard filters and collection modalities for DAF-2DA green fluorescence. Images were processed and analyzed using the ImageJ software.

\subsection{Peroxynitrite Detection}

The level of peroxynitrite was assayed using folic acid as the peroxynitrite scavenger, giving high fluorescent emission products [55]. Hyphae $(0.5 \mathrm{~g})$ were immersed in the incubation mixture, containing barbital buffer solution ( $\mathrm{pH}$ 9.4) (Warchem; Marki, Poland) and folic acid $\left(1.0 \times 10^{-5} \mathrm{~mol} \mathrm{~L}^{-1}\right.$ ) (Merck; Kenilworth, NJ, USA). Fluorescence intensity of the solution was recorded at $460 \mathrm{~nm}$ with the excitation wavelength set at $380 \mathrm{~nm}$. The standard curve was prepared for 3-Morpholinosydnonimine (SIN-1) from Calbiochem as a donor of peroxynitrite at the range of concentration from 1 to $14 \mathrm{nM}$. 


\subsection{Protein 3-Nitrotyrosine Assay}

Hyphae of $P$. infestans $(0.2 \mathrm{~g})$ were ground in liquid nitrogen to a fine powder, then it was suspended in buffer containing $50 \mathrm{mM}$ Tris- $\mathrm{HCl}$ (pH 7.6) (Bio-Rad; Hercules, CA, USA) with $2 \mathrm{mM}$ EDTA (BioShop), 2 mM DTT (Sigma; Saint-Louis, MO, USA), and 1 mM PMSF (Sigma; Saint-Louis, MO, USA). After centrifugation $\left(10,000 \mathrm{~g}\right.$ for $15 \mathrm{~min}$ at $\left.4{ }^{\circ} \mathrm{C}\right)$ the supernatant was collected and the protein concentration was determined with the Bradford [56] assay. 3-nitrotyrosine in a protein sample was measured using the OxiSelect ${ }^{\mathrm{TM}}$ Nitrotyrosine ELISA Kit (Cell Biolabs; San Diego, CA, USA; STA-305) according to the manufacturer's protocol. Optical density was measured at $450 \mathrm{~nm}$ using an IMARK ${ }^{\mathrm{TM}}$ Microplate Reader (Bio-Rad; Hercules, CA, USA). The 3-nitrotyrosine content in protein samples was determined by comparing with the predetermined 3-nitrotyrosine standard curve. Each sample was analyzed in triplicate on ELISA microplates.

\subsection{Protein Carbonylation Assay}

The level of carbonylated proteins (PCO) was evaluated acording to Colombo et al. [57]. Briefly, $P$. infestans protein samples at concentration of $1 \mathrm{mg} / \mathrm{mL}$ were incubated in the dark for $1 \mathrm{~h}$ with 2,4-dinitrophenylhydrazine (DNPH) (Sigma; Saint-Louis, MO, USA) solution. Then, $1.2 \mathrm{~mL}$ of $20 \%$ TCA (Sigma; Saint-Louis, MO, USA) was added to protein samples and incubated on ice for $15 \mathrm{~min}$. After centrifugation $\left(10,000 \mathrm{~g}\right.$ for $5 \mathrm{~min}$ at $\left.4{ }^{\circ} \mathrm{C}\right)$, protein pellet was washed twice with $1 \mathrm{~mL}$ of $20 \%$ TCA. Next, the pellet was washed with $1 \mathrm{~mL}$ of ethanol:ethyl acetate (1:1 v/v) solution (P.O.Ch.; Gliwice, Poland) in order to remove any free DNPH, and then samples were centrifuged (10,000 $g$ for $10 \mathrm{~min}$ at $4^{\circ} \mathrm{C}$ ). The pellet was dried out and next resuspended in $1 \mathrm{~mL}$ of $6 \mathrm{M}$ guanidine hydrochloride (Sigma; Saint-Louis, MO, USA) at $37^{\circ} \mathrm{C}$ for $15 \mathrm{~min}$. The absorbance was measured at $366 \mathrm{~nm}$. The calculation of PCO content was based on the fact that the molar extinction coefficient $(\varepsilon)$ for DNPH at $375 \mathrm{~nm}$ is $22,000 \mathrm{M}^{-1} \mathrm{~cm}^{-1}$.

\subsection{RNA Extraction}

Hyphae of $P$. infestans were frozen in liquid nitrogen and stored at $80{ }^{\circ} \mathrm{C}$ until use. For RNA extraction hyphae $(0.150 \mathrm{~g})$ were ground to a fine powder and total RNA was extracted using TriReagent (Sigma; Saint-Louis, MO, USA) according to the manufacturer's instructions.

\subsection{DNA Extraction}

Hyphae of $P$. infestans were frozen in liquid nitrogen and stored at $80{ }^{\circ} \mathrm{C}$ until use. For DNA extraction hyphae $(0.150 \mathrm{~g})$ were ground to a fine powder and then homogenized in buffer containing $200 \mathrm{mM}$ Tris- $\mathrm{HCl}$ (pH 7.5) (Bio-Rad; Hercules, CA, USA), $250 \mathrm{mM} \mathrm{NaCl}$ (Stanlab; Lublin, Poland), 25 mM EDTA (BioShop; Mainway, Burlington, ON, Canada), 10\% SDS (Sigma; Saint-Louis, MO, USA), and RNase A (ThermoFisher; Waltham, MA, USA) was added to each sample. After incubation (30 min at RT with mixing) the phenol-chloroform-isopropanol mixture (1:2:1) (BioShop; Mainway, Burlington, $\mathrm{ON}$, Canada) was added and samples were mixed. After centrifugation $\left(10,000 \mathrm{~g}\right.$ for $12 \mathrm{~min}$ at $\left.4{ }^{\circ} \mathrm{C}\right)$ the upper layer was collected, mixed with chloroform, and centrifuged $\left(10,000 \mathrm{~g}\right.$ for $12 \mathrm{~min}$ at $\left.4{ }^{\circ} \mathrm{C}\right)$. Then the upper layer was mixed with isopropanol, incubated for $10 \mathrm{~min}$ at RT, and centrifuged $(10,000 \mathrm{~g}$ for $12 \mathrm{~min}$ at $4{ }^{\circ} \mathrm{C}$ ). The supernatant was removed, the precipitate was air dried, and dissolved in $\mathrm{H}_{2} \mathrm{O}_{\text {DEPC }}$.

\subsection{8- $\mathrm{NO}_{2}-\mathrm{G}$ Quantification}

The level of 8-nitroguanine was quantified with the OxiSelect ${ }^{\mathrm{TM}}$ Nitrosative DNA/RNA Damage ELISA Kit (Cell Biolabs; San Diego, CA, USA; STA-825). For the analysis $10 \mu \mathrm{g}$ of total RNA or DNA were used. Further procedures were carried out according to the manufacturer's instructions. The absorbance of the samples was measured at a wavelength of $450 \mathrm{~nm}$ using an IMARK ${ }^{\mathrm{TM}}$ Microplate 
Reader (Bio-Rad; Hercules, CA, USA). The 8- $\mathrm{NO}_{2}-\mathrm{G}$ content was determined by comparing with the predetermined 8- $\mathrm{NO}_{2}-\mathrm{G}$ standard curve. Each sample was analyzed in triplicate on ELISA microplates.

\subsection{Total Antioxidative Capacity}

Total antioxidative capacity (TAC) was determined based on the ability of the antioxidants present in the extract to reduce the 2,2' azinobis-(3-ethylbenzothiazoline-6-sulfonic acid) (ABTS) cation radical according to Bartosz [58]. The initial $\mathrm{ABTS}^{+}$solution was diluted with $0.1 \mathrm{M}$ potassium phosphate buffer (pH 7.4) (Chempur; Piekary Ślaskie, Poland) to set absorbance at a wavelength of $414 \mathrm{~nm}$ on 1.0. Hyphae ( $0.1 \mathrm{~g})$ were homogenized in $0.8 \mathrm{~mL}$ of $5 \%$ TCA (Sigma; Saint-Louis, MO, USA). After centrifugation $\left(15,000 \mathrm{~g}\right.$ for $30 \mathrm{~min}$ at $\left.4{ }^{\circ} \mathrm{C}\right)$ the supernatant was collected and used for assays. The volume of $980 \mu \mathrm{L}$ diluted $\mathrm{ABTS}^{+}$was added to a cuvette and absorbance (A0) at a wavelength of $414 \mathrm{~nm}$ was measured. Then, $20 \mu \mathrm{L}$ of the extract was added and absorbance was measured again after $10 \mathrm{~s}$ (A2) and $30 \mathrm{~min}$ (A1), respectively. Fast antioxidants were calculated as $\Delta \mathrm{A}_{\text {fast }}=\mathrm{A} 1-\mathrm{A} 0$, whereas slow antioxidants were calculated as $\Delta \mathrm{A}_{\text {slow }}=(\mathrm{A} 2-\mathrm{A} 1)-\left(\mathrm{A} 2^{\prime}-\mathrm{A} 1^{\prime}\right)$. The calibration curve was prepared by successively adding $5 \mu \mathrm{L}$ portions of $0.01 \mathrm{mM}$ Trolox ${ }^{\circledR}$ (Sigma; Saint-Louis, MO, USA) to $\mathrm{ABTS}^{+}$and measuring a decrease of absorbance. The final result of total antioxidative capacity was expressed in $\mathrm{mM}$ Trolox $\times \mathrm{g}^{-1} \mathrm{FW}$.

\subsection{Superoxide Dismutase Activity}

Superoxide dismutase was assayed by measuring SOD ability to inhibit the photochemical reduction of NBT using the method of Beauchamp and Fridovich [59]. Fresh hyphae $(0.05 \mathrm{~g})$ were homogenized in 0.05 M sodium-phosphate buffer (pH 7.0) (Chempur; Piekary Ślaskie, Poland), containing 1 mM EDTA (BioShop; Mainway, Burlington, ON, Canada), 1\% PVPP (Sigma; Saint-Louis, MO, USA), and $0.01 \mathrm{M}$ $\mathrm{NaCl}$ (Stanlab; Lublin, Poland). After centrifugation $\left(15,000 \mathrm{~g}\right.$ for $30 \mathrm{~min}$ at $\left.4{ }^{\circ} \mathrm{C}\right)$ the supernatant was collected and used for assays. The assay mixture contained $0.05 \mathrm{M}$ sodium phosphate buffer (pH 7.8) (Chempur; Piekary Ślaskie, Poland), 13 mM methionine (Sigma; Saint-Louis, MO, USA), $75 \mu \mathrm{M}$ NBT (SERVA; Heidelberg, Germany), enzymatic extract, and $2 \mu \mathrm{M}$ of riboflavin (SERVA; Heidelberg, Germany). The reaction was initiated by UV radiation $(15 \mathrm{~W})$ and was run for $15 \mathrm{~min}$. The absorbance was measured at a wavelength of $560 \mathrm{~nm}$. The amount of the enzyme that caused inhibition of the NTB reduction reaction by $50 \%$ was assumed as a unit of SOD activity ( $\mathrm{U} \times \mathrm{mg}^{-1}$ protein). To determine SOD isoenzymes a samples containing $50 \mu \mathrm{g}$ of protein were separated in a $10 \%$ nondenaturing acrylamide gel and visualized using the method of Beauchamp and Fridovich [59].

\subsection{Catalase Activity}

Catalase was assayed using the method of Chance and Maehly [60]. Fresh hyphae (0.250 g) were homogenized in $0.1 \mathrm{M}$ sodium-phosphate buffer ( $\mathrm{pH}$ 7.0) (Chempur; Piekary Ślaskie, Poland). After centrifugation $\left(15,000 \mathrm{~g}\right.$ for $30 \mathrm{~min}$ at $\left.4{ }^{\circ} \mathrm{C}\right)$ the supernatant was collected and used for assays. The assay mixture contained $0.01 \mathrm{M}$ sodium-phosphate buffer ( $\mathrm{pH}$ 7.0), enzymatic extract, and 3\% $\mathrm{H}_{2} \mathrm{O}_{2}$. Absorbance was measured at a wavelength of $240 \mathrm{~nm}$. The catalase activity was expressed as $\Delta \mathrm{A}$ $\times \mathrm{min}^{-1} \times \mathrm{mg}^{-1}$ protein. Catalase isoenzymes were determined by native PAGE on $7.5 \%$ acrylamide gels and were localized by the method described earlier by Woodbury et al. [61]. To determine CAT isoenzymes a samples containing $50 \mu \mathrm{g}$ of protein were separated in a $7.5 \%$ nondenaturing acrylamide gel and visualized using the method of Woodbury et al. [61].

\subsection{Gene Expression Measurement}

Hyphae of $P$. infestans (or potato leaves) were frozen in liquid nitrogen and stored at $-80^{\circ} \mathrm{C}$ until use. The RNA was isolated from $0.150 \mathrm{~g}$ of frozen sample using TriReagent (Sigma; Saint-Louis, MO, USA). The obtained RNA was purified with the use of the Deoxyribonuclease Kit (Sigma). For the reverse transcription $1 \mu \mathrm{g}$ of RNA was processed with the Reverse Transcription Kit (Thermo Scientific Fermentas; Waltham, MA, USA) according to the manufacturer's instructions. The real-time PCR 
reactions were performed on a Rotor-Gene 6000 thermocycler (Corbett Life Science; Qiagen; Hilden, Germany). The reaction mixture contained $0.1 \mu \mathrm{M}$ of each primer (listed in Table S1 in Supplementary Materials), $1 \mu \mathrm{L}$ of $5 \times$ diluted cDNA, $5 \mu \mathrm{L}$ of Power SYBR Green PCR Master mix (Applied Biosystems; Foster City, CA, USA), and DEPC treated water to a total volume of $10 \mu \mathrm{L}$. The PCR reaction initiated denaturation at $95^{\circ} \mathrm{C}$ for $5 \mathrm{~min}$. Subsequent stages included 50 cycles consisting of $10 \mathrm{~s}$ at $95^{\circ} \mathrm{C}, 20 \mathrm{~s}$ at $53^{\circ} \mathrm{C}$, and $30 \mathrm{~s}$ at $72{ }^{\circ} \mathrm{C}$. The reaction was finalized by denaturation at a temperature rising from 72 to $95^{\circ} \mathrm{C}$ by one degree every $5 \mathrm{~s}$. The reaction specificity and CT values for individual samples were determined using the real-time PCR Miner Program [62]. The P. infestans S3a gene was selected as a reference in P. infestans gene expression measurement; the potato $E f 1-\alpha$ gene was selected as a reference in expression analysis of the PiTef1 in planta. All primers used are presented in Table S1. The relative gene expression was calculated using the Pfaffl mathematical model [63].

\subsection{Statistical Analysis}

All results are based on three biological replicates derived from three independent experiments. For each experiment, means of the obtained values ( $n=9$ or in case of the assessment of the area under disease progress $n=15$ ) were calculated along with standard deviations. To estimate the statistical significance between means, the data were analyzed with the use of one-way analysis of variance (ANOVA) followed by a Dunnett's test at the level of significance $\alpha=0.05$ or $\alpha=0.01$.

Supplementary Materials: The following are available online at http://www.mdpi.com/1422-0067/21/21/8375/s1, Table S1. Sequences of primers used for the real-time PCR reaction; Figure S1. The effect of various Cd concentrations on $P$. infestans in vitro growth; Figure S2. The effect of $\mathrm{Cd}$ on the selected elements of the enzymatic antioxidant system in P. infestans; Figure S3. The original source photo (full-length gel) for Figure 6G showing isoenzyme patterns of SOD; Figure S4. The original source photo (full-length gel) for Figure $6 \mathrm{H}$ showing isoenzyme patterns of CAT.

Author Contributions: Conceptualization (conceived the ideas and designed the experiment), M.A.-J. and J.F.-W.; Formal analysis, investigation, J.G., N.A.A., Ö.A.B., K.I.-J. and T.J.; Validation, M.A-J., J.F.-W and J.D.; writing—original draft preparation, J.G., M.A.-J.; writing—review and editing, M.A.-J., J.F.-W. and J.D.; supervision and project administration, M.A-J. All authors have read and agreed to the published version of the manuscript.

Funding: This research was co-financed by National Science Centre-project no. NCN 2014/13/B/NZ9/02177, the grant of Dean of the Faculty of Biology AMU—project no. GDWB-09/2019 and within the framework of Ministry of Science and Higher Education programme as "Regional Initiative Excellence" in years 2019-2022- project no. 005/RID/2018/19.

Conflicts of Interest: The authors declare no conflict of interest.

\section{Abbreviations}

$\begin{array}{ll}\mathrm{CAT} & \text { catalase } \\ \mathrm{Cd} & \text { cadmium } \\ \mathrm{FW} & \text { fresh weight } \\ \mathrm{NO} & \text { nitric oxide } \\ 8-\mathrm{NO}_{2}-\mathrm{G} & \text { 8-nitroguanine } \\ \mathrm{ONOO}^{-} & \text {peroxynitrite } \\ \mathrm{PCO} & \text { carbonylated proteins } \\ \mathrm{RNS} & \text { reactive nitrogen species } \\ \text { ROS } & \text { reactive oxygen species } \\ \text { SOD } & \text { superoxide dismutase } \\ \text { TAC } & \text { total antioxidative capacity }\end{array}$

\section{References}

1. Candelone, J.P.; Hong, S.; Pellone, C.; Boutron, C.F. Post Industrial Revolution changes in large-scale atmospheric pollution of the northern Hemisphere by heavy metals documented in central Greenland snow and ice. J. Geophys. Res. 1995, 100, 16605-16616. [CrossRef] 
2. Maanan, M.; Saddik, M.; Maanan, M.; Chaibi, M.; Assobhei, O.; Zourarah, B. Environmental and ecological risk assessment of heavy metals in sediments of Nador lagoon, Morocco. Ecol. Indic. 2015, 48, 616-626. [CrossRef]

3. Wu, Q.; Zhou, H.; Tam, N.F.Y.; Tian, Y.; Tan, Y.; Zhou, S.; Li, Q.; Chen, Y.; Leung, J.Y. Contamination, toxicity and speciation of heavy metals in an industrialized urban river: Implications for the dispersal of heavy metals. Mar. Pollut. Bull. 2016, 104, 153-161. [CrossRef] [PubMed]

4. Gadd, G.M. Interactions of fungi with toxic metals. In The Genus Aspergillus; Powell, K.A., Renwick, A., Peberdy, J.F., Eds.; FEMS Springer: Boston, MA, USA, 1994; p. 69.

5. Ali, E.H.; Hashem, M. Removal Efficiency of the heavy metals $\mathrm{Zn}(\mathrm{II}), \mathrm{Pb}(\mathrm{II})$ and $\mathrm{Cd}(\mathrm{II})$ by Saprolegnia delica and Trichoderma viride at different $\mathrm{pH}$ values and temperature degrees. Mycobiology 2007, 35, 135-144. [CrossRef] [PubMed]

6. Gallego, S.M.; Pena, L.B.; Barcia, R.A.; Azpilicueta, C.E.; Iannone, M.F.; Rosales, E.P.; Zawoznik, M.S.; Groppa, M.D.; Benavides, M.P. Unravelling cadmium toxicity and tolerance in plants: Insight into regulatory mechanisms. Environ. Exp. Bot. 2012, 83, 33-46. [CrossRef]

7. Chmielowska-Bąk, J.; Izbiańska, K.; Ekner-Grzyb, A.; Bayar, M.; Deckert, J. Cadmium stress leads to rapid increase in RNA oxidative modifications in soybean seedlings. Front. Plant Sci. 2018, 8, 2219. [CrossRef] [PubMed]

8. Rodríguez-Serrano, M.; Romero-Puertas, M.C.; Pazmiño, D.M.; Testillano, P.S.; Risueño, M.C.; Del Río, L.A.; Sandalio, L.M. Cellular response of pea plant to cadmium toxicity: Cross talk between reactive oxygen species, nitric oxide and cadmium. Plant Physiol. 2009, 150, 229-243. [CrossRef] [PubMed]

9. Bailey-Serres, J.; Mittler, R. The roles of reactive oxygen species in plant cells. Plant Physiol. 2006, $141,311$. [CrossRef]

10. Finkel, T. Signal transduction by reactive oxygen species. J. Cell Biol. 2011, 194, 7-15. [CrossRef]

11. Turkan, I. ROS and RNS: Key signalling molecules in plants. J. Exp. Bot. 2018, 69, 3313-3315. [CrossRef] [PubMed]

12. Pauly, N.; Pucciariello, C.; Mandon, K.; Innocenti, G.; Jamet, A.; Baudouin, E.; Hérouart, D.; Fredo, P.; Puppo, A. Reactive oxygen and nitrogen species and glutathione: Key players in the legume-Rhizobium symbiosis. J. Exp. Bot. 2006, 57, 1769-1776. [CrossRef]

13. Zhang, Q.; Zeng, G.; Chen, G.; Yan, M.; Chen, A.; Du, J.; Huang, J.; Yi, B.; Zhou, Y.; He, X.; et al. The effect of heavy metal-induced oxidative stress on the enzymes in white rot fungus Phanerochaete chrysosporium. Appl. Biochem. Biotechnol. 2015, 175, 1281-1293. [CrossRef] [PubMed]

14. Englender, C.M.; Corden, M.E. Stimulation of mycelial growth of Endothia parasitica by heavy metals. Appl. Microbiol. 1971, 22, 1012-1016. [CrossRef]

15. Cuero, R.T.; Ouellet, T.J.; Yu, J.; Mogongwa, N. Metal ion enhancement of fungal growth, gene expression and aflatoxin synthesis in Aspergillus flavus: RT-PCR characterization. J. Appl. Microbiol. 2003, 94, 953-961. [CrossRef] [PubMed]

16. Abu-Mejdad, N. Response of some fungal species to the effect of copper, magnesium and zinc under the laboratory condition. Eur. J. Exp. Biol. 2013, 3, 535-540.

17. Mwangi, E.S.K.; Gatebe, E.G.; Ndung'u, M.W. Effect of selected metal ions on the mycelial growth of Sclerotinia sclerotiorum isolated from soybean field in Rongai, Kenya. IJCMR 2014, 2, 116-125.

18. Baldrian, P. Interactions of heavy metals with white-rot fungi. Enzym. Microb. Technol. 2003, 32, 78-91. [CrossRef]

19. Golubović-Ćurguz, V.; Tabaković-Tošić, M.; Veselinović, M.; Rajković, S. The influence of the heavy metals on the growth of pathogenic fungi. For. Ideas 2010, 16, 39.

20. Ouda, S.M. Antifungal activity of silver and copper nanoparticles on two plant pathogens, Alternaria alternata and Botrytis cinerea. Res. J. Microbiol. 2014, 9, 34-42. [CrossRef]

21. Sazanova, K.; Osmolovskaya, N.; Schiparev, S.; Yakkonen, K.; Kuchaeva, L.; Vlasov, D. Organic acids induce tolerance to zinc- and copper-exposed fungi under various growth conditions. Curr. Microbiol. 2015, 70, 520-527. [CrossRef] [PubMed]

22. Lazarova, N.; Krumova, E.; Stefanova, T.; Georgieva, N.; Angelova, M. The oxidative stress response of the filamentous yeast Trichosporon cutaneum R57 to copper, cadmium and chromium exposure. Biotechnol. Biotechnol. Equip. 2014, 28, 855-862. [CrossRef] 
23. Lundy, S.D.; Payne, R.J.; Giles, K.R.; Garrill, A. Heavy metals have diferent effects on mycelial morphology of Achlya bisexualis as determined by fractal geometry. FEMS Microbiol. Lett. 2001, 201, 259-263. [CrossRef]

24. Ali, E.H. Comparative study of the effect of stress by the heavy metals $\mathrm{Cd}^{+2}, \mathrm{~Pb}^{+2}$, and $\mathrm{Zn}^{+2}$ on morphological characteristics of Saprolegnia Delica Coker and Dictyuchus Carpophorus Zopf. Pol. J. Microbiol. 2007, 56, 257-264.

25. Liu, P.; Wei, M.; Zhang, J.; Wang, R.; Li, B.; Chen, Q.; Weng, Q. Changes in mycelia growth, sporulation, and virulence of Phytophthora capsici when challenged by heavy metals $\left(\mathrm{Cu}^{2+}, \mathrm{Cr}^{2+}\right.$ and $\left.\mathrm{Hg}^{2+}\right)$ under acid $\mathrm{pH}$ stress. Environ. Pollut. 2018, 235, 372-380. [CrossRef]

26. Resjö, S.; Brus, M.; Ali, A.; Meijer, H.; Sandin, M.; Govers, F.; Levander, F.; Grenville-Briggs, L.; Andreasson, E. Proteomic analysis of Phytophthora infestans reveals the importance of cell wall proteins in pathogenicity. Mol. Cell. Proteomics 2017, 16, 1958-1971. [CrossRef]

27. Fry, W. Phytophthora infestans: The plant (and R gene) destroyer. Mol. Plant Pathol. 2008, 9, 385-402. [CrossRef]

28. Forbes, G.A. Using host resistance to manage potato late blight with particular reference to developing countries. Potato Res. 2012, 55, 205-216. [CrossRef]

29. Qiu, L.; Wang, K.; Long, W.; Wang, K.; Hu, W.; Amable, G.S. A comparative assessment of the influences of human impacts on soil $\mathrm{Cd}$ concentrations based on stepwise linear regression, classification and regression tree, and random forest models. PLoS ONE 2016, 11, e0151131. [CrossRef]

30. Khan, M.A.; Khan, S.; Khan, A.; Alam, M. Soil contamination with cadmium, consequences and remediation using organic amendments. Sci. Total Environ. 2017, 601, 1591-1605. [CrossRef] [PubMed]

31. Izbiańska, K.; Floryszak-Wieczorek, J.; Gajewska, J.; Gzyl, J.; Jelonek, T.; Arasimowicz-Jelonek, M. Switchable nitroproteome states of Phytophthora infestans biology and pathobiology. Front. Microbiol. 2019, 10, 1516. [CrossRef] [PubMed]

32. Castello, P.R.; David, P.S.; McMlure, T.; Crook, Z.; Poyton, R.O. Mitochondrial cytochrome oxidase produces nitric oxide under hypoxic conditions: Implications for oxygen sensing and hypoxic signaling in eukaryotes. Cell Metab. 2006, 3, 277-287. [CrossRef]

33. Chiang, K.T.; Switzer, C.H.; Akali, K.O.; Fukudo, J.M. The role of oxygen and reduced oxygen species in nitric-oxide-mediated cytotoxicity: Studies in the yeast Saccharomyces cerevisiae model system. Toxicol. Appl. Pharmacol. 2000, 167, 30-36. [CrossRef]

34. Domitrovic, T.; Palhano, F.L.; Barja-Fidalgo, C.; DeFreitas, M.; Orlando, M.T.; Fernandes, P.M. Role of nitric oxide in the response of Saccharomyces cerevisiae cells to heat shock and high hydrostatic pressure. FEMS Yeast Res. 2003, 3, 341-346. [CrossRef]

35. Orłowska, E.; Fiil, A.; Kirk, H.G.; Llorente, B.; Cvitanich, C. Differential gene induction in resistant and susceptible potato cultivars at early stages of infection by Phytophthora infestans. Plant Cell Rep. 2012, 31, 187-203. [CrossRef]

36. Jaworska, M.; Gorczyca, A. Effect of metal ions on entomopathogenic fungi pathogenicity. Ecol. Chem. Eng. 2004, 11, 327-339.

37. Bakti, F.; Sasse, C.; Heinekamp, T.; Pócsi, I.; Braus, G.H. Heavy metal-induced expression of PcaA provides cadmium tolerance to Aspergillus fumigatus and supports its virulence in the Galleria mellonella model. Front. Microbiol. 2018, 9, 744. [CrossRef]

38. Lorenzo-Gutiérrez, D.; Gómez-Gil, L.; Guarro, J.; Roncero, M.I.G.; Fernández-Bravo, A.; Capilla, J.; López-Fernández, L. Role of the Fusarium oxysporum metallothionein Mt1 in resistance to metal toxicity and virulence. Metallomics 2019, 11, 1230-1240. [CrossRef]

39. Gill, M. Heavy metal stress in plants: A review. Int. J. Adv. Res. 2014, 2, 1043-1055.

40. Pengkit, A.; Jeon, S.S.; Son, S.J.; Shin, J.H.; Baik, K.Y.; Choi, E.H.; Park, G. Identification and functional analysis of endogenous nitric oxide in a filamentous fungus. Sci. Rep. 2016, 6, 30037. [CrossRef]

41. Arasimowicz-Jelonek, M.; Floryszak-Wieczorek, J. A physiological perspective on targets of nitration in NO-based signaling networks in plants. J. Exp. Bot. 2019, 70, 4379-4389. [CrossRef] [PubMed]

42. Hoernes, T.P.; Erlacher, M.D. Translating the epitranscriptome. WIREs RNA 2017, 8, e1375. [CrossRef]

43. Ilyas, S.; Kim, M.S.; Lee, J.C.; Jabeen, A.; Bhatti, H.N. Bio-reclamation of strategic and energy critical metals from secondary resources. Metals 2017, 7, 207. [CrossRef]

44. Han, Y.; Zhao, B.; Zhang, M.; Hong, Y.; Han, H.; Cao, X.; Lu, K.; Lin, J.; Fu, Z. Biochemical properties and vaccine effect of recombinant TPx-3 from Schistosoma japonicum. Parasitol. Res. 2017, 116, 1361-1372. [CrossRef] [PubMed] 
45. Ighodaro, O.M.; Akinloye, O.A. First line defence antioxidants-superoxide dismutase (SOD), catalase (CAT) and glutathione peroxidase (GPX): Their fundamental role in the entire antioxidant defence grid. Alex. J. Med. 2018, 54, 287-293. [CrossRef]

46. Chen, A.; Zeng, G.; Chen, G.; Liu, L.; Shang, C.; Hu, X.; Lu, L.; Chen, M.; Zhou, Y.; Zhang, Q. Plasma membrane behavior, oxidative damage, and defense mechanism in Phanerochaete chrysosporium under cadmium stress. Process Biochem. 2014, 49, 589-598. [CrossRef]

47. Floryszak-Wieczorek, J.; Arasimowicz-Jelonek, M. Contrasting regulation of NO and ROS in potato defense-associated metabolism in response to pathogens of different lifestyles. PLoS ONE 2016, 11, e0163546. [CrossRef] [PubMed]

48. Warris, A.; Ballou, E.R. Oxidative responses and fungal infection biology. Semin. Cell Dev. Biol. 2019, 89, 34-46. [CrossRef]

49. Stroiński, A.; Woźny, A.; Floryszak-Wieczorek, J. Effects of cadmium on the host-pathogen system II. Alterations of potato tuber and Phytophthora infestans relations. Biochem. Physiol. Pflanzen. 1990, 186, 229-238. [CrossRef]

50. Stroiński, A.; Floryszak-Wieczorek, J.; Woźny, A. Effects of cadmium on the host-pathogen system I. Alterations of potato leaves and Phytophthora infestans relations. Biochem. Physiol. Pflanzen. 1990, 186, $43-54$. [CrossRef]

51. Park, J.I.; Grant, C.M.; Attfield, P.V.; Dawes, I.W. The freeze-thaw stress response of the yeast Saccharomyces cerevisiae is growth phase specific and is controlled by nutritional state via the ras-cyclic amp signal transduction pathway. Appl. Environ. Microbiol. 1997, 63, 3818-3824. [CrossRef]

52. Arasimowicz-Jelonek, M.; Floryszak-Wieczorek, J.; Izbiańska, K.; Gzyl, J.; Jelonek, T. Implication of peroxynitrite in defence responses of potato to Phytophthora infestans. Plant Pathol. 2016, 65, 754-766. [CrossRef]

53. Doke, N. Generation of superoxide anion by potato tuber protoplasts during the hypersensitive response to hyphal wall components of Phytophthora infestans and specific inhibition of the reaction by suppressors of hypersensitivity. Physiol. Plant Pathol. 1983, 23, 359-367. [CrossRef]

54. Becana, M.; Aparicio-Tejo, P.; Irigoyen, J.J.; Sanchez-Diaz, M. Some enzymes of hydrogen peroxide metabolism in leaves and root nodules of Medicago sativa. Plant Physiol. 1986, 82, 1169-1171. [CrossRef]

55. Huang, J.C.; Li, D.J.; Diao, J.C.; Hou, J.; Yuan, J.L.; Zou, G.L. A novel fluorescent method for determination of peroxynitrite using folic acid as a probe. Talanta 2007, 72, 1283-1287. [CrossRef]

56. Bradford, M.A. Rapid and sensitive method for the quantitation of microgram quantities of protein utilising the principle of protein-dye binding. Anal. Biochem. 1976, 72, 248-254. [CrossRef]

57. Colombo, G.; Clerici, M.; Garavaglia, M.E.; Giustarini, D.; Rossi, R.; Milzani, A.; Dalle-Donne, I. A step-by-step protocol for assaying protein carbonylation in biological samples. J. Chromatogr. B Biomed. Appl. 2016, 1019, 178-190. [CrossRef] [PubMed]

58. Bartosz, G. Total antioxidant capacity. Adv. Clin. Chem. 2003, 37, 219-292.

59. Beauchamp, C.; Fridovich, I. Superoxide dismutase-Improvement assays and an assays applicable to acrylamide gels. Anal. Biochem. 1971, 44, 276-287. [CrossRef]

60. Chance, B.; Maehly, A.C. An assay of catalase and peroxidase. In Methods in Enzymology; Colowick, S.P., Kapland, N.D., Eds.; Academic Press: New York, NY, USA, 1995; pp. 764-791.

61. Woodbury, W.; Spencer, A.K.; Stahmann, M.A. An improved procedure using ferricyanide for detecting catalase isozymes. Anal. Biochem. 1971, 44, 301-305. [CrossRef]

62. Zhao, S.; Fernald, R. Comprehensive Algorithm for Quantitative Real-Time Polymerase Chain Reaction. J. Comput. Biol. 2005, 12, 1047-1064. [CrossRef]

63. Pfaffl, M.W. A new mathematical model for relative quantification in real-time RT-PCR. Nucleic Acids Res. 2001, 29, e45. [CrossRef]

Publisher's Note: MDPI stays neutral with regard to jurisdictional claims in published maps and institutional affiliations. 